\title{
Political textbooks in a political world: A case-study of an Estonian history textbook
}

\author{
J. Berkeley Bentley \\ West Virginia University
}

Follow this and additional works at: https://researchrepository.wvu.edu/etd

\section{Recommended Citation}

Bentley, J. Berkeley, "Political textbooks in a political world: A case-study of an Estonian history textbook" (2011). Graduate Theses, Dissertations, and Problem Reports. 727.

https://researchrepository.wvu.edu/etd/727

This Thesis is protected by copyright and/or related rights. It has been brought to you by the The Research Repository @ WVU with permission from the rights-holder(s). You are free to use this Thesis in any way that is permitted by the copyright and related rights legislation that applies to your use. For other uses you must obtain permission from the rights-holder(s) directly, unless additional rights are indicated by a Creative Commons license in the record and/ or on the work itself. This Thesis has been accepted for inclusion in WVU Graduate Theses, Dissertations, and Problem Reports collection by an authorized administrator of The Research Repository @ WVU. For more information, please contact researchrepository@mail.wvu.edu. 
POLITICAL TEXTBOOKS IN A POLITICAL WORLD: A CASE-STUDY OF AN ESTONIAN HISTORY TEXTBOOK

\author{
J. Berkeley Bentley
}

\begin{abstract}
Thesis submitted to the Eberly College of Arts and Sciences at West Virginia University in partial fulfillment of the requirements for the degree of
\end{abstract}

Master of Arts

in History

\author{
Robert Blobaum, Ph.D., Chair \\ Joshua Arthurs, Ph.D. \\ Elizabeth Fones-Wolf, Ph.D. \\ Department of History
}

\author{
Morgantown, West Virginia \\ 2011
}

Keywords: Narrative Construction; Narrative Interpretation; Estonian Historical Narrative 


\title{
ABSTRACT \\ Political Textbooks in a Political World: A Case-Study of an Estonian History Textbook
}

\begin{abstract}
J. Berkeley Bentley
In the 1990s, the Estonian state was characterized by a relatively rapidly developing political scene. The developments occurred in such a short time period as to render the national history textbook ineffective and thus ill-suited to its perceived use as a tool of socialization into the state, providing an excellent case-study of the limitations of the relationship between textbook and state. This study analyzes the narrative of an Estonian national history textbook produced in the mid 1990s and uses the product of that narrative analysis to map the shifting political winds as represented in the professional rhetoric of the Estonian head-of-state over the course of that textbook's conception, production, and use in Estonian public high schools: from 1994 through the 1998 school year. The results of this study are an identification of the driving threads of the Estonian historical narrative presented in the textbook and a view of the changing interpretation and reconstruction of that historical narrative by President Lennart Meri over the course of the time period studied.
\end{abstract}




\section{ACKNOWLEDGEMENTS}

I must especially thank Dr. Heiko Paabo of the University of Tartu and Dr. Robert Blobaum of West Virginia University for their guidance and patience over the course of the writing of this thesis as well as to those two and Dr. Serge Pukas of Collegium Civitas in Warsaw, Poland, for the opportunity to participate in the Transatlantic Atlantis M.A. Program for which this Master's thesis was written. Thank you. 


\section{TABLE OF CONTENTS}

Introduction $\quad 1$

Chapter One: Theoretical Framework $\quad 9$

$\begin{array}{ll}\text { Theory } & 9\end{array}$

Literature Review $\quad 23$

Methodology 27

Chapter Two: Application 33

Narrative Construction: Textbook Analysis 33

Narrative Interpretation: Speech Analysis 44

$\begin{array}{ll}\text { Conclusions } & 50\end{array}$

Bibliography 53 


\section{INTRODUCTION}

In an interview given several months after the ethnically-charged riots in Tallinn over the removal of the statue of "The Bronze Soldier," ${ }^{1}$ Estonian President Toomas Hendrik Ilves was asked to respond to then-Russian President Vladimir Putin's accusation that Estonia was rewriting history. President Ilves responded that, "Yes, in fact we do want to rewrite history" (Spiegel 2007). He went on to describe an example of how the old Soviet textbook contained just one line about the gulags, mentioning only that they had been closed. In the rewriting of Estonian history over the last twenty years, more information and more facts were introduced into the textbooks wherever the censors of the Soviet Union had previously been compelled to scrub them clean of the most shameful and violent incidents of the communist regime's past. But in the writing of this modern Estonian history, more than just the names, dates, places, and pacts which make up the memorizable character of history were introduced. For although "history is composed of facts, there is something more to history, something that makes it more than just the sum of its factual claims. That something has a technical name . . . narrative” (Immerwahr 2008, p. 199). ${ }^{2}$ It is that narrative and its interpretation with which this thesis is concerned.

What makes the construction of an Estonian historical narrative of particular interest for study is the last twenty years of history, politics, and social relations in Estonia. The (re)independence of the Estonian state from the USSR and its accession and acceptance into the

\footnotetext{
${ }^{1}$ In April 2007, the Estonian government moved a statue, “The Bronze Soldier,” erected in commemoration of the arrival of Soviet troops in 1944, and the removal of the Nazi occupation force, from a small park in the center of Tallinn to a cemetery on the outskirts of the capital. The statue has been the site of "competing memories" of the Soviet period, largely along ethnic and linguistic lines (e.g., the statue was the destination of school field trips from Russian-speaking Estonian schools). The riots which erupted on the $26^{\text {th }}$ and $27^{\text {th }}$ of April 2007 can be seen as resulting from the competing memories of Estonia's Soviet past and the narratives already formed in the minds of Estonian citizens today. For a full discussion of this incident in the context of "competing memories," see Wertsch 2008.

${ }^{2}$ Narrative, in this thesis, can be defined simply as the story constructed of the events and personalities of history. This particular definition takes on importance, especially, in the Literature Review chapter as ideas of identity and collective memory are unpacked, and the construction of narrative is fully developed. For the purposes of this Introduction, "narrative” does not assume anything more than to be particular representation of events.
} 
EU and NATO, as well as the elections of Presidents Meri, Ruutel, and Ilves, are some of the events which will be written into the Estonian history books. The riots between a faction of Russian-speaking Estonians and ethnic-Estonians in northeastern Estonia and Tallinn, too, will most likely make it into the general history books. What is of interest in the history textbook for this study is the "particular connections between events. The connections [made] between the events is the meaning" (emphasis in original, Coulter \& Smith 2009, p. 578). These connections, as well as the depiction of the events and personalities in a textbook and, in fact, which events and personalities receive attention at all, are all part of the makeup of the narrative of the history textbook.

This study focuses on a much-used Estonian history textbook, History of Estonia (1997), ${ }^{3}$ in its analysis of a constructed narrative. That the analysis focuses on this single textbook is important because of the nature of the textbook, in a preponderance of the scholarship, ${ }^{4}$ in its role as an agent of socialization of a society's youth (e.g., Kalmus 2003). In the textbook, it is not merely the events (or names, places, and pacts) themselves which the student learns, but also the narrative presented by the text. The student also learns the connections and transitions between events as constructed in the narrative of the history textbook. Moreover, "textbooks carry the authority of print" (Podeh 2000, p. 67), "which separate[s] speech from speaker, and that separation in itself makes the words impersonal, objective and above criticism" (Olson 1989, p. 241; quoted in Podeh 2000, p. 67). The textbook is also a meaningful object of study for the current thesis because "the process of [textbook knowledge]'s manufacture is . . . intensely political” (Crawford 2003b, p. 5). This is important because of the unique politics characterizing Estonia since the years just prior to the collapse of the Soviet Union when opposition voices really started to become conspicuous.

In the years just before and after Estonia regained its independence from the Soviet Union, a peculiar political and social climate was prevalent among the citizenry and especially among the intellectual and cultural elite of Estonia, those who most influence the process of

\footnotetext{
${ }^{3}$ Laur, M., Lukas, T., Pajur, A., \& Tannberg, T. (2000). History of Estonia. Tallinn, Estonia: Avita. Originally published 1997: Avita. This (2000) edition is a translated edition. The Estonian edition which has been directly translated was published in 1997, and the first edition in 1995.

${ }^{4}$ The fact that so much emphasis has been placed on the history textbook's, especially but also the school system's, influence on the socialization of a society's youth is important, regardless of the debate about just how much influence any text has over a student or similar debates, because it is not the effectiveness of this narrative, rather the possibility for the existence of multiple, competing or conflicting, narratives from the state itself at any given moment which this thesis attempts to illuminate.
} 
textbook production. That climate fostered active debate and liberal to radical economic and political ideas. It has been said that school textbooks as "social constructions manufactured within particular climates of opinion . . present official versions of publicly sanctioned knowledge” (Mirkovic and Crawford 2003, p. 91). Thus the politics of that time should be, according to the overwhelming majority of the literature, reflected in the narrative constructed for the Estonian history textbook. In the twenty years since Estonia regained its independence and began its efforts at the building of a sovereign nation-state, the politics of that day-dictated by the needs and the capacities of that day - have given way to the politics of each day sincelikewise dictated by the needs and capacities of the time. The narrative presented in the textbook has not kept up, and truly cannot keep up, with this changing politics.

When viewed as an agent of socialization into the state, this textbook narrative reflects decisions from a different set of concerns than those of the day when the student actually reads the textbook and internalizes the narrative presented within. In this light, identity formation opens itself to contradictions as different messages about the state are concurrently presented within the static text and from contemporary, and ever-changing, political messages like speeches and new policies. This study analyzes the narrative of an Estonian history textbook and sets that narrative into the context of the time period when it was in use in Estonian public high schools. The construction of the narrative presented in the Estonian history textbook under study took place in a time and from a politics which were very much concerned with issues of nationbuilding like identity formation and (importantly) its subsequent protection, issues which, later in the textbook's use, took a backseat in the Estonian political dialogue to issues of European integration and economic growth and development, though these issues did not entirely disappear. This changing political scene in Estonia over the course of the relatively short time frame studied in this thesis provides a unique opportunity to see the extent to which the interpretation $^{5}$ of a national historical narrative can both hold onto the old and react to the new ideas and trends in society.

Of course, a textbook is updated and rewritten to some extent every so often with each new edition. To update or rewrite, however, involves less narrative construction than is required to create in the first place. It follows, then, that an updated edition of an original text will likely

\footnotetext{
${ }^{5}$ The act of interpreting, it must be said up front, is actually a construction, or reconstruction, itself of that narrative according to whatever knowledge a person has at the moment of interpretation. Thus every subsequent interpretation builds from prior interpretations as well as the original construction of the historical narrative.
} 
retain the original narrative to a large extent. The larger historical narrative for Estonia was retained from the interwar period, so the depiction of an ancient independent Estonian people has been a part of the Estonian narrative, though not officially, for much longer than the past twenty years. That narrative still had to be re-recorded in the 1990s. So the political climate of that time rather than simply a reproduction of the interwar narrative will be presented in a contemporary textbook. The textbook under analysis here is the second edition, the first edition having been published in 1995. Analysis should thus anticipate a narrative in-line with the nation- and statebuilding rhetoric of the early and mid 1990s, according to the argument of this paper, as opposed to a narrative more conducive to the political needs of the government of the late 1990s when Estonia was invited to begin talks of accession to the European Union.

This narrative analysis of the Estonian national history textbook is then set into a political and temporal context by a subsequent analysis of the rhetoric of the Estonian president throughout that period, President Lennart Meri. The speeches of this head of state are read from the context of that textbook narrative to trace a changing interpretation of the Estonian narrative for contemporary political needs in order to demonstrate that differing conceptions of the nation, historically and therefore in terms of the possibilities for tomorrow, will be propagated by sources seen as authoritative to the citizenry: the national history textbook and the speech of the head of state.

The lag between the needs of the state, contemporarily, and the narrative presented to society's youth through textbooks is compounded by the realities of the textbook publishing process. That is, the time and the resources necessary to publish these agents of socialization make the textbook inherently disadvantageous to the political needs of any future government. The particular narrative constructed and published is thus preserved and propagated for as long as the textbook remains in use. Relatively small changes in the political environment, therefore, will not carry the impetus necessary to expend state resources on new textbooks carrying a slightly updated ${ }^{6}$ narrative.

The present study will analyze an Estonian history textbook used in Estonian public high schools in the 1990s to identify the narrative or narratives constructed in the textbook. The nature of that narrative is then set in the context of the changing political realities of the Estonian

\footnotetext{
6 “Updated” here is meant politically, i.e., to better serve the changed political reality, rather than to refer to the new editions of history textbooks put out every so often to include more recent events.
} 
government over time to determine the orientation of what much scholarship has said to represent officially sanctioned (e.g., Mirkovic and Crawford 2003, p. 91) knowledge from the state, the textbook, to the political rhetoric of the a head of state itself. Thus, my research questions are the following: What is the relationship between what is deemed one of the most powerful tools of socialization (the national history textbook) and the state into which the readership is being socialized? More pointedly, and derived from the singularity of this Estonian case-study: To what extent and in what ways will the historical narrative presented in a national history textbook lessen or even lose its effectiveness as a tool of socialization, given a changing political reality? The very nature of textbook production-as a time and resource consuming political construct-limits the responsiveness of this particular agent of socialization to the political and social needs of the state. Yet the power of the textbook to socialize a society's youth is still tapped in each new edition to further the political aims of today. The purpose of this study is to provide a case-study of this relationship through an examination of the narrative presented in a widely-used Estonian national history textbook and the Estonian political environment of the late 1990s when that textbook was being used.

As this thesis draws from several academic disciplines, the literature is of a diverse background and focus. Some related studies focused on Estonia have looked primarily at the construction of historical narrative or national identity and the causes or effects of that narrative on contemporary (e.g., Ehin and Berg 2009) or historical (e.g., Feest 2007) relations with the larger regional political powers or the domestic ethnic relations and tensions as creating or resulting from a narrative antagonistic to the Russian-speaking minority in Estonia (e.g., Bruggemann and Kasekamp 2008), among others. Studies focused more specifically on the construction of historical narrative have examined the different narratives of the same event (e.g., Crawford 2007), treatment of minority groups in historical narratives (e.g., Janmaat 2007, 2005), and more general studies of textbooks and curricula in transition (e.g., Schissler and Soysal 2005). These studies focus very much upon the narratives presented in the text and how they change. No study, however, has examined the textual narratives as the static snapshots of (negotiated) political motives which this study seeks to describe. This "lag" between the construction of a historical narrative and its dissemination is what is to be identified and described in this thesis. As the state relies upon socialization processes to prosper or even survive, this lag seems especially important for its practical value as an object of study. 
The research method used in this study is based from Erickson's (1986) determination of a good interpretive analysis, though the initial analysis is informed by some generic questions found to have been applied in textbook content analysis in Nichol and Dean's (2003) study of "Methods of School Textbook Research” (p. 20) and serve as starting points of general inquiry. In brief, the researcher reads and rereads the body of evidence as a whole and generates preliminary assertions based from the narrative of the body. The data supporting and contradicting each assertion is then assembled and weighed. Those assertions which do not stand up to this process are discarded or redefined according to the data once assembled and more closely analyzed. A system of organization is implemented, linking the assertions to one another in a hierarchical manner. Where this differs from Erickson's suggestions for the good interpretivist researcher is that his analysis concludes with the construction of a vignette, complete with actors and arc. This study leaves bare the analysis, preferring to highlight the vignette presented in the textbook itself. This study will deconstruct the narrative into its component threads and then reconstruct them only to the extent necessary to suggest the general themes of the narrative presented in the textbook (Coulter and Smith 2009, p. 587). The drive of the narrative is broken down into distinct but related assertions. These assertions then serve as a standard against which can be read the ever-evolving interpretation of the national historical narrative presented in the speeches of President Meri (1992-2001) which informs the political environment for this study. Finally, the speeches themselves are contextualized to some extent, providing some commentary from the larger Estonian public discourse over the course of study and his speeches.

A limitation of this study is one likely encountered by any scholar foreign to the Baltic region and its particular languages, here, the Estonian language. The textbook under analysis is a translated edition from Estonian into English. One problem for this study presented by a translated primary source is that any nuances of the language or the connotations of certain words in either the original Estonian or the translated English must be discounted as evidence of the constructed narrative because of the probability that those nuances have been lost (or created) in translation. Another problem is that the English-language edition may have more or less material than the original Estonian. This is the case for some Russian-language editions of textbooks, notably civics textbooks (Kalmus 2003, p. 19). Because of the role of the history textbook as "the grand narrative of the nation" (Rosser 2003, p. 446), however, it is assumed that 
the narrative presented in the English-language edition has not been changed to an intolerable extent for research purposes. A civics textbook teaches student-readers to be citizens of the state. Therefore, it is logical that the Russian-language edition of an Estonian civics textbook would, for example, give "more attention to the issues of integration, citizenship, and human rights"7 (Kalmus 2003, p. 19), issues unlikely to become part of the grand narrative of the nation state.

Another possible limitation of this study is two-fold and results from the objects of study themselves. First, this study focuses on one Estonian history textbook, not all history texts in use in Estonian schools. Though a broad study of all the Estonian history textbooks would better identify overarching themes of the national narrative, the focus of this study allows a more thorough reading of a particular narrative. This is advantageous for the current study because it aims to determine the specific orientation of a specific narrative in relationship to the high politics of the period. A second limitation of the textbook which needs mentioning is that there are noted problems in the literature regarding the study of textbooks, generally. Here, suffice it to say that the study of textbooks is a rich field of scholarship despite these problems. Though it is "difficult to estimate the role of educational media in general and the actual contribution of a single textbook in particular” (Kalmus 2003, p. 6), the textbook is still an important object of study as one of many agents of socialization, especially since so much weight is attached and so much attention paid to it from scholars, politicians, and the public alike. Focusing the analysis of the interpretation of historical narrative solely on the speeches of President Lennart Meri, too, serves as a limitation as well for many of the same reasons. First, not everything which would constitute the political rhetoric of a statesman is available in the English language, thus the data pool is relatively small. Second, President Meri's is but one voice and cannot be said to represent the voice of Estonia at any given moment. President Meri's position, his stature at home and abroad, and his background as a historian, however, do justify this choice as his was most probably the most respected voice in Estonian politics in the years under study here. The limitations of this study are not inconsequential; but nor are they of too much consequence to make the study irrelevant for its contribution to the field or for its practical implications.

This study aims at recognizing the lasting consequence of the construction of a historical narrative in a specific political climate. The climate prevalent in times of great economic strife and political upheaval is a much more powerful force than is the climate prevalent in times of

\footnotetext{
${ }^{7}$ Veronika Kalmus found this to have been the case in her 2003 doctoral dissertation.
} 
economic prosperity and routine politics. It follows, then, that a narrative constructed during one period, especially of a state- and nation-building Estonia in the early 1990s, will show distinct features of that narrative during a different, more conventional political period.

The thesis is organized in the following manner: In the first chapter, the theory underlying this thesis's argument is accounted, followed by a review of the literature most relevant to this study and an explication of the methodology spelled out in brief above. In the next chapter, the empirical data, those general assertions drawn from the textbook narrative, are accounted along with explanations as to why each is presented as such. These assertions are then used to map the changing interpretation of the national narrative presented in the speeches of President Meri over the life of the textbook narrative's conception, production, and dissemination to the country's school-age population.

According to John Gillis, "National identities are, like everything historical, constructed and reconstructed; and it is our responsibility to decode them in order to discover the relationships they create and sustain" (1994, p. 4; citing Hobsbawm 1993). It is the job of this thesis to discover the relationship between different means of identity construction and reinforcement. It is hoped that through such an examination of the potential for conflicting representations of the state as informed by constructions of national memory, the textbook's limitations as a force for socialization will be brought to the fore. The narrative constructed in a textbook is read and internalized (to some degree) by each student who must study from it. So while shoring up the present state of affairs is important, too much emphasis on any particularly biased construction of a historical narrative may impair the ability of the leadership of tomorrow to be responsive to a changing political scene at home or abroad. 
CHAPTER ONE: THEORETICAL FRAMEWORK

This chapter presents the framework for this study. First, the theoretical framework is developed, outlining theories of identity and memory construction and collectivization and demonstrating that two sources of the same nation's historical narrative may differ greatly over a relatively short period of time because of the nature of narrative construction for reasons of social and political expedience. Next, the literature relevant to this study is reviewed and it is demonstrated that no study to date has questioned the makings of national history and memory as this study proposes to do. Finally, the methodological choices of this study are presented, offering justifications for methodological variations from other studies.

\section{THEORY}

It is theorized that the narrative constructed in a textbook will provide the reader with a different conception of the nation's history (which serves to inform the present circumstances as well as project itself into the future) than the reader will receive elsewhere from similarly authoritative sources by the time the textbook is published and put into use in the nation's schools. The nature of the textbook can make it disadvantageous to the political needs of those in power at any subsequent date after the textbook's narrative is finalized. This inherent element of textbook production is made especially conspicuous because what is in fact produced is one recorded version of an ever-malleable national memory. National memory is constructed according to the aims of those who construct the narrative, and those actors are usually politically and 
ideologically driven toward a particular conception of the state. Thus, if any change to society, politics, the economy, etc., is effected after the text is finalized by these actors, the textbook narrative becomes disadvantageous because the decisions which led to its particular construction would have been made from a different time and reality; and any variation, any different or new information, could have altered particular decisions altogether.

Different conceptions of the nation's history (and therefore different lenses through which to view today's society and tomorrow's possibilities) being propagated simultaneously by different sources will result in dissonance in the receiver (reader of the textbook or audience member to a speech) to some extent. This resulting dissonance is exactly the opposite of the intended purpose of an agent of socialization: to bring a group together through shared experiences, norms, beliefs, and language, and to do so in order to create a good and loyal citizenry. Therefore, the textbook is ill-suited to its perception (and resultant use) as one of the most powerful agents of socialization.

This is not to say that the textbook should not be used as such an agent—nor does this author believe that it could ever be the case that the textbook would stop influencing its readership in important ways. Rather, it is to say that the textbook's power as an agent of socialization should always be in the minds of its authors, and that that power should be tempered with an eye toward the future rather than simply the politics of the present. Many studies have focused on the potentially harmful effects of a particular narrative, especially nationally-minded narratives of history. The social problems created or at least left unresolved by such constructions are, of course, real problems in the writing of histories. And while pointing this out is one purpose of this study —as it has been at least a secondary purpose in previous studies of historical narrative - this thesis also hopes to shed light on the more mundane political advantages of a temperance of passions in the construction of a national historical narrative. A moderate politics does not always exist in societies, nor should it. But a dispassionate written history should exist, if for nothing else than the political advantages to be had from a generation socialized into a middle-of-the-road politics.

Constructing an Identity \& Creating a Memory 
A written history is an account of the collective memory of a society, one constructed by individuals with their own interests, aims, and individual memories. Neither nations nor governments, nor any institution or social groups "have” a memory - they "make” their memory (Assmann 2008). Unlike individual memories, national memories are not the products of the events of history themselves. Rather a national memory is a social product, the creation of a process of transmittal from one individual to another, and so on, establishing a common sense of a shared past. This national memory is rarely explicitly expressed in words from person to person, however. Shared experiences including those moments and monuments of commemoration to that past are what bond most of a citizenry. While the individual is constantly in dialogue with the national memory as regards his own place in relation to it, the process of constructing that national memory has long had a profoundly political character. Since the rise of the nation-state, the motivations for and means of recording a national history have been the state's own. Thus the job of defining the fixed form of the national memory has been in the hands of those in power who seek to retain that power. With the emergence of mass politics in the late $19^{\text {th }}$ Century, political leaders rediscovered the importance of identifying some “irrational" elements in society as those elements actually serve to maintain the "rational" or majority elements in society by providing something against which the majority could easily be judged (Olick 1998, p. 117). Thus, successful leaders required means to portray the situation as such. The opportunity to do so was provided by the creation of a robust and enduring civil religion which was both created and reinforced through educational institutions with nationalist content. Public ceremonies began to be held in earnest from these political motivations and the mass production of public monuments to hail the nation's glorious past was started in order to exploit this new concept (Ibid).

National memories and national identities are constructions or representations of reality (Gillis 1994, p. 3). The national memory gives shape to the national identity by providing a "sense of sameness over time and space” (Ibid). National memories are subjective rather than objective products of collective will or thought and, therefore, propagate differing ideas about the state depending upon the particular authors as well as the moment of their production. In this context, the national identity is constantly reworking the national memory to best suit current circumstances in a simultaneous negotiation between the national memory and national identity. 
Every individual in society plays a part in shaping and propagating the national memory as his or her individual memory of either events themselves or recreations of those events (e.g., textbook representations in school) constantly negotiates a place for itself within the larger popular collective memory of those events. A particular construction of the national memory resides in each nationally-conscious person but takes on a much larger meaning when it is recorded and, especially, transmitted throughout the population.

The means by which the national memory is recorded, and therefore constructed for posterity, largely privilege a particular class of society. The elites of a society command the resources of the state, politically and economically, and, therefore, socially as well through control of the media. These elites then use those resources in order to legitimize the status quo arrangement of society which benefits them-as evidenced by their status as elites in this circular arrangement. Perpetuation of the status quo is seen here as a primary motivating factor in most top-down constructions of national memory-i.e., those constructions recorded and massproduced for dissemination (which require significant economic and political capital to create). Even in moments of great political upheaval when just what and who constitutes the elite is being reformulated, it is still a desire to create and then perpetuate a new status quo better suited to the new construction of society driving a particular construction of memory.

There are several institutional mechanisms by which the elites can influence the construction of the national memory and thereby shape the national identity. In society, every group in which one participates will affect the development of the individual. The most powerful of these forces are those controlled and directed by the state as it is those bodies, rather than voluntary civic organizations, for example, which are best served by a particular mode of socialization as they need to be viewed as legitimate by society in order to function or even to continue in existence. The institutions of the state, like the military and the school system, are thus very powerful agents of a particular socialization, that desired by the state. The construction of the state espoused in these institutions is internalized through these institutional mechanisms, though to state to what degree can only be done retrospectively and on an individual basis and lies outside the realm of this thesis.

The national education system is seen as perhaps the most important of these agents of socialization into society, that which is both shaped and served by the elites. Schools have been found to play an important role in reproducing the social structure as well as transmitting the 
ideology of a regime (Apple 1979). ${ }^{8}$ The advantages of this system to the state are several. First, there is simply a large amount of time in which to socialize the young and impressionable generation of citizens within the school system. Youth often spend more time, or more active effective time, in schools as opposed to at home with family or among other peer groups. Second, there is much impetus placed on conformity within the school as good careers and prestige in the community are most often conditional upon success in school (Theiler 1999, pp. 312-313; cited in Segesten 2009). Much scholarship has been devoted to this political element of the school system and the possibilities for exploitation of it. Studies of the post-Soviet space, especially, have looked at the school system as an effective means of constructing "new" states in place of the "old” Soviet republics and satellites. ${ }^{9}$ International organizations like UNESCO have created manuals for the writing of history books in an effort to decrease nationalist and militarist tendencies in the writing of national histories. As Anamarie Segesten has argued, The mechanisms that have the potential to bring people together and sow the seeds of values such as freedom, tolerance and cooperation may also be the same paths followed by states or political leaders who seek to benefit from inter-ethnic tensions, societal violence and discriminatory practices. If one admits that education can also be part of the problem, then reforming education, identifying the trouble areas, can be part of an initiative not only to correct the disastrous effects of conflicts but also to preempt them (2009, p. 4).

Survey research has shown that popular history is often a collective memory of conflicts of the core group against other groups, either peripheral or entirely foreign. These collective memories make up the background and support for prescriptive charters which legitimize certain roles and mandate actions from policy makers. These policy makers are thus responding to the popular collective memory, especially in matters of defense, as well as the pressures the elites are seen to

\footnotetext{
${ }^{8}$ That the reproduction of the social structure is in the best interests of the current elites hardly needs stated. That transmitting the ideology of a regime is in the interests of the elites follows because of the investment the elites have in the current political arrangement and, in the reverse, because of the necessity of elite money and influence to effectively work in politics.

${ }^{9}$ Here, it is important to state the Estonian case in relation to other post-Soviet states, as it would seem that any of these states would serve as a good case-study. From the collapse of the Soviet Union came "new" states, all of which created or recreated historical narratives. The Estonian case, however, is unique because of the speed of ascendance from a collapsing Soviet system to the successes Estonia achieved over the course of the 1990s to today, economically and politically - as a lot of corruption still lingers in parts of this post-Soviet space. This is especially pertinent because of the changing political reality over the time period covered here while this particular textbook was in use.
} 
bring to bear on the process of the construction of national memory and identity when constructing policy (Liu and Laszlo 2007).

The opportunities presented to the state through exploitation of the textbook are many and follow from the advantages presented above by the school system itself. School-age children are, again, a very impressionable group within society. In many fields, the information provided through textbooks represents the sole trusted source of information on the subject, making the textbook representations of events the most likely representation to be believed to be fact (Kalmus 2003). That first introduction to information will likely remain with the student until some other information is presented that is more persuasive or better fits with whatever other knowledge the child acquires throughout his life. That this information is presented by an elder and a person in a role of authority, of course, only adds to the likelihood that the information presented will be taken unquestioningly as fact. Peer groups, of course, are a very powerful socializing force. But at a young age, especially, peers can seldom speak from as much knowledge as their teachers.

Even when a teacher is viewed by a child as someone who is not necessarily an expert on a particular subject, however, the textbook, as a written resource, carries "the authority of print" (Podeh 2000). Further, "The institutional and, thus, authoritative nature of textbook texts" (Kalmus 2003, p. 33), combined with its status as a written resource-“impersonal, objective, and above criticism" (Olson 1980, p. 192; quoted in Luke, de Castell, and Luke 1983, p. 113)— make the textbook the most authoritative source of information available to a student. In today's modern age, too, with so much information available at the student's command over the internet, Podeh (2000) has concluded that textbooks, as compared to other socializing agents such as television, radio, newspapers, etc., have remained a powerful socializing factor in the age of electronic media. ${ }^{10}$ Scholars largely agree with Jacbomeyer's (1990) assessment that the textbook remains "the most remarkable medium for the transmission of history, outnumbering press, radio and TV" (p. 8).

No doubt one reason for the textbook's enduring importance is the fact that it is an excellent source of testable knowledge. Along these same lines, studies of textbooks have found that the textbooks are often used as a sort of outline for the courses, frequently determining both

\footnotetext{
${ }^{10}$ However, there has been a trend lately toward E-books for public consumption, something which will undoubtedly catch on for school systems because of a number of factors, not the least of which deal with the financial expenditures necessary for actual printed materials to be produced.
} 
the content and structure of class-time (McCutcheon 1981). ${ }^{11}$ In fact, "Both historical reports (from the beginning of the century) and more recent research indicate that from $75 \%$ to $90 \%$ of classroom instructional time is structured by textbook programs” (Woodward 1998, p. 7, cited in Segensten 2009). Even more conservative estimates would betray a heavy reliance upon the textbook in a school system which controls a very significant portion of most days of a young person's life. This situation presents a great opportunity to manipulate the textbook portrayal of the nation's experience in order to depict a particular construction of history, one which both informs the present and shapes the future citizenry. And because of the political world through which these textbooks must pass before a student receives it, that opportunity is exploited in response or preemption to those pressures. ${ }^{12}$

Preemptive action, here, is important because these forces are rarely manifested as directives. These pressures are societal, though the resources brought to bear are those of the elites. The generation writing the textbook is never the first generation. Therefore what is written today is influenced by the past experiences of socialization from the authors' own formative years. This is important, here, for two reasons. First, in the Estonian case, the formative years of those responsible for the production of an Estonian national history took place under Soviet domination. The texts from which they read were almost purely objects of propaganda. So confronted with conflicting narratives by official (Soviet government) and unofficial ${ }^{13}$ (e.g., family) authorities during these years, once the Soviet regime fell and Estonia reclaimed its sovereignty, the unofficial narrative was recorded as the official narrative under their own hands. So this narrative was informed by the Estonian narrative from the interwar period as well a

\footnotetext{
${ }^{11}$ Practical concerns such as these underlie much of the discussion of the textbook's political character. As there is a need for testable material and as there is a market which rewards the producer who presents the best and most economical product - here, one which contains the "right" story with a good amount of supplemental materials to steer course work - the best product will often be one which can be used for its content and the structure it provides. The logic of the textbook producer, then, is to include as much material as possible in whatever light desired by the body choosing or approving the textbook for the cheapest price to the purchasing body. That logic proceeds directly from that of the state which should look for the textbook which first, contains the right information; second, portrays the correct narrative; and third, provides a good outline for a course so students of different classes and different schools get the most consistent education - both for consistent socialization of that generation (within the state schools, at least) and for simplicity of testing the knowledge acquired and retained.

${ }^{12}$ This point follows from the same logic as the footnote above. In order to get a textbook published, it must be the "right" textbook in the eyes of the powers that be.

${ }^{13}$ A fuller discussion of "official” and "unofficial” memories comes later and references Paabo 2010.
} 
reaction against the Soviet narrative imposed for over four decades. Second, and following from the first point, it shows one extreme outcome of socialization under conflicting narratives. ${ }^{14}$

That opportunity for exploitation advantages the elites of society because of their representation within the political community, which is responsible for selecting a text, and in the business community, ${ }^{15}$ a part of which actually constructs the narrative of the history textbook. Crawford (2003a), in an editorial on “The Role and Purpose of Textbooks,” described the results of a number of studies, concluding that the manufacture of textbook content is the result of competition between powerful groups in society, including political and business community leaders (p. 5). Other studies have come to similar conclusions, finding a domination of the process by a few working to legitimize a particular set of values and who support a conventional view of society as opposed to supporting a culturally or ideologically pluralist view of society (Kalmus 2003). This process results in the construction of a particular narrative of the state, one constructed by the elites of society and meant to legitimize and thus perpetuate the current social and political arrangement. ${ }^{16}$ It must be said, however, that each of those doing the constructing, contemporarily, underwent the same processes of socialization-though to different ends - during their own formative years. That experience is what sets the limits of practical exploitation in the present, though those limits may have been stretched greatly over time.

As national identity and national memory are mutually constitutive, a nation which has recently experienced great political upheaval, such as Estonia in the early 1990s, is placed into a situation where the "new" national identity will be vastly different from the national identity previously propagated officially through a particular construction of the national memory. In fact, the national identity in the Estonian case represents an antithesis of the former, Soviet Estonian national identity (Paabo 2010, p. 2). The unofficial history kept alive during Soviet rule through the private sphere which challenged the official Soviet one enabled the Estonians to restore the Estonian narrative constructed during the interwar period rather than create a new identity wholly against the experience of Soviet domination (Tulviste and Wertsch 1998, pp.

\footnotetext{
${ }^{14}$ Both of these points make the political speeches of President Lennart Meri important for study, here, as Meri was both a product of this socialization as well as being a professional historian, himself shaping the recorded versions of the Estonian narrative. This is returned to later.

${ }^{15}$ Here, the publishing industry, as only an established publishing house could handle an order for mass-production of a textbook.

${ }^{16}$ The competition which does exist between actors is mitigated in terms of the power to change the social structures because of the barriers to entry into that competition-i.e., only elites compete.
} 
311-329; Bennich-Björkman 2007, pp. 1-21; cited from Paabo 2010). That domination, however, still played a large part in shaping the "new” Estonian national memory and identity because of the need to define oneself against an Other in order to create a practical and realistic sense of Self.

Iver Neumann's Uses of the Other (1999) provides a good history as well as the theory behind this dichotomy. Hegel introduced this paradigm when he stated that "Each is for the other the middle term through which each mediates itself” (1977, p. 112). Identity formation, generally, is a relational process requiring the conceptual pairing of and differentiation between the Self and an Other (Neumann 1998). After all, there must be some context for whatever label one ascribes to oneself. This is true for both the individual's identity and the group's identity. Neither is a fixed concept. The Self is defined by the Other and vice versa. To claim one identity is to deny another, a foreign and often dehumanized identity. This paradigm isn't used to define essentially different peoples. Rather, it is put into use to define those who share aspects of identity, save for some politically defining characteristics. As "identity requires difference in order to be ... it converts difference into otherness in order to secure its own self-certainty” (Connolly 1991, p. 64; quoted in Kuus 2002). Once an Other is defined and the Self in relation to it at the state level, an Us can be "constructed through shared practices and discourses that mark certain boundaries and define principles of inclusion and exclusion” (Assmann 2008). Likewise, the Other will develop from a de facto group (because of the label attributed by whomever develops the "Self/Other” relationship at first) into an Us as well, if no more appropriate group identity is available.

That Russia represents the primary Other in the Estonian case is well supported in the scholarship. Because of the geographical proximity, regional historical dominance, and historical relationship between Estonia and Russia, a securitization of the Estonian identity has also been found in studies of Estonian identity creation and development since regaining independence. This securitization of identity against non-Estonian and foreign, and especially Russian, influences created a nationalistic, ethnically conscious, and suspicious citizenry (Kuus 2002). Because of the historical events still prevalent in the individual memories of the citizenry, to say nothing of the constructed collective memory here, Estonian culture and language were very important as unifying factors in the early reformulation of Estonian national identity at the beginning of the 1990s. These same factors have been found to be major reasons for the Estonian 
identity's survival over such a long period of foreign rule. Taagepera (1993, pp. 5-6) has emphasized the difference of the language from most of its neighbors, geographical and political isolation from linguistic kinfolk, and the major religious border, which all serve to reinforce the distinct Estonian identity. With a history of keeping the language and elements of culture alive, at least in the private sphere, the Estonian identity long had to deal with threats to its survival. So when the newly independent Estonia of the 1990s turned its efforts to identity creation, a long period of imperial rule was still born in mind. Thus Mirkovic and Crawford's (2003) assessment that such conditions can create a situation in which "teaching a nationalistic and mono-cultural form of history can be the cement which binds people together" (p. 92) becomes of especial interest for the current study. The teaching of a mono-cultural form of history, especially when nationality is dependent on that culture, will lead to a distancing from neighbors as well as any minority cultures domestically.

Opposition to some outside force, "alien rule" (Berg 2002, p. 112), is very important to identity construction. Such an impetus is more than enough grounds to imbue history textbooks with an appropriately nationalistic narrative and use them as "weapons of mass instruction" (Ingrao 2007; quoted from Assmann 2008). In this situation, it is through learning the nation's history that the "heterogeneous members of a population [are] transformed into a distinct and homogeneous collective, conceiving of themselves as a 'people' with a collective 'autobiography' " (Assmann 2008). This creation of a people through a particular narration of the state's history can be justified by the constructed identity itself. The Estonian identity has been found to have been constructed from a narrative that "portray[s] the Soviet era as an 'occupation,' which in Estonia . . . destroyed the demographic balance by increasing the share of the Russophone population ... due to reasons such as deportations, war losses, intentional Soviet policies of resettlement of ethnic groups and voluntary migration” (Aalto 2003, p. 574). The Estonian language laws (Rannut 2004) were attempts at actual rectification of those imbalances created under Soviet rule. However, the result was not only to rectify past wrongs but to distance part of the population, the Russophone Estonians, from the popular and propagated conception of the Self. So the positive_-“This is us"—and negative—-"That isn't"—identification mechanism (Assmann \& Czaplicsa 1995) lends itself especially well to an Estonian case study. 
Rogers Brubaker, writing of nationalizing nationalisms in the Introduction to his Nationalism Reframed: Nationhood and the National Question in the New Europe (1996), said that

Despite having 'its own' state . . . the core nation is conceived as being in a weak cultural, economic, or demographic position within the state. This weak position — seen as a legacy of discrimination against the nation before it attained independence-is held to justify the 'remedial' or 'compensatory' project of using state power to promote the specific (and previously inadequately served) interests of the core nation (p. 5).

This can be seen as a fair summation of the direction Estonian policy took in the early days after the reinstatement of Estonian independence as the Estonian political elite chose a restitutionist interpretation of independence, using historical premises from the interwar period which allowed it to promote the development of Estonian national identity, language, and culture through constitutional provisions at the expense, largely, of those who settled in Estonia during the Soviet period (Berg 2002).

The Estonian identity has developed not only as markedly distinct from a Russian identity and the old Soviet state, but also as a part of the new enlarged Europe. Before accession to the EU and NATO, President Meri said, "On one side is Europe, on the other side, Russia. We are on the border and therefore only a small push is needed to make us fall into one side or rise into the other” (Berg 2007, p. 49). Meri’s dichotomous language, falling backward or rising forward, was characteristic of the government's rhetoric soon after the reinstatement of independence. Berg (2002) has said that "West and East have been antipodes for Estonian selfconstruction, reflecting the dichotomy of Europeanisation and Russification, goodies versus baddies" (emphasis in original, p. 127). Such representations work to identify with the "good," but create distance from the "bad." It must be remembered that, although this differentiation is a necessary part of identity politics, this constitution of good versus bad entails costs for that group considered to be the bad Other (Neumann 1999, p. 158), here namely Russia. Some scholarship, however, points to a trend of securitization against all foreign influences and has been said to be characterized by an essentialized and exclusionary notion of identity (Feldman 2001). The main themes of this scholarship are the uniqueness of Estonian culture and economics, and the relationship of the two. There is a fear that a "Return to Europe" (Feldman 2001) would be 
accompanied by subordination to a global supranational government and the loss of the recently regained sovereign state. Reliance on foreign aid-leading to dependence upon foreign bodiesin an effort to "Return” and general global trends toward cultural homogenization could result from "this borderless world," which could threaten “to break the last barriers which separate 'us' from 'them,' [and] makes the 'self' insecure and rather unclear” (Berg 2002, p. 110). Construction of an Estonian identity in the 1990s was the result of competing groups in society, comprised primarily of the elites. This competition manifested itself in conflicting identity narratives, one more oriented toward isolationism in the face of international pressures, the other oriented toward the West and represented by the European Union and NATO.

In political terms, "Self-interest presupposes an other” (Wendt 1994). But which Other and just how that Other is constructed and portrayed are the products of competition in society between those dominant groups. Iver Neumann concludes of the study of this Self/Other pairing, that "Analyses of self/other nexuses hold out the promise of a better understanding of who 'the actors' are, how they were constituted, how they maintain themselves, and under which preconditions they may thrive” (1999, p. 37). Analysis of the Estonian representations of this relationship is important to identify those societal forces responsible for the several and changing constructions of the Estonian national memory and identity. And analysis of the two constructions of this relationship analyzed here identifies the political trajectory of this debate over its course from the middle to late 1990s in Estonia.

"The study of collective memory ... is much more than the unidimensional study of the past. It represents a graphing of the past as it is used for present aims, a vision in bold relief of the past as it is woven into the present and future” (Zelizer 1995, p. 217). Used as such, the collective memory is constantly changing and being renegotiated. But that does not mean that past conceptions of the collective memory change just as quickly. Nor does it mean that the collective memory as recorded yesterday ceases to be an effective translator of that memory to whoever reads it. That vision in bold relief of the past as it is woven into the present and future instead continues to stand as a part of the collective memory to be negotiated by the individual, along with other influences and experiences of that individual, in relation to himself. As described earlier, one powerful recorded national memory is represented in the nation's history textbook. While most textbooks, save those of less transparent authoritarian regimes (Segesten 2008, p. 140), will not represent too overtly biased a construction of the national memory, the 
memory as recorded in textbooks is still highly dependent upon a particular narrative to tell the story of the nation's (glorious or victimized) past.

Which particular narrative is constructed and then propagated is the result of negotiations between those who control the economic resources and those intimate in the politics of a state. "The paradox of narrative is that it is a universally human mechanism of communication and cognition, but at the same time, the form of knowledge created by this mechanism is validated and maintained in time and space as a part of a particular society’s beliefs” (Liu \& Laszlo 2007, p. 4). This is especially true of the textbook. Because of those factors discussed above-i.e., the authority of printed materials, the seemingly neutral and objective nature of the textbook, the large and impressionable audience, etc.- the narrative constructed and recorded in a textbook is a very powerful force of socialization to future generations of the citizenry.

Because this is not the only agent of socialization, however, that citizenry is presented with multiple constructions of the national narrative, each of which reflects different circumstances from which it was constructed and each of which is meant to socialize its audience differently. The static textbook construction is, in this thesis, analyzed against the changing political constructions ${ }^{17}$ of the same historical narrative as presented in President Lennart Meri's speeches over the time period the textbook was developed, produced, and in use in schools. These speeches aren't constructions of the national historical narrative in the same way as the textbook portrayal of this narrative. Meri’s speeches, rather, are a practical application of a particular construction of that narrative. They reflect an individual's understanding and negotiation of himself to the larger national narrative as described above. That Lennart Meri was a charismatic and very nationally-minded head of state, as well as his own personal history as the son of an ambassador and himself a historian of Estonian and the Finno-Ugric peoples, ${ }^{18}$ makes his individual negotiation interesting and important as an object of study. As head of state, Meri was the symbolic leader of the Estonian state, domestically and abroad, throughout his presidency. Each speech over this time period was directed toward a specific audience, was

\footnotetext{
${ }^{17}$ See footnote 5: the act of interpreting a narrative is, in fact, reconstructing that narrative with each new interpretation, each of which is constructed with the previous interpretations rather than solely from one formal constructed narrative.

18 The source for all biographical information on President Meri is from "Lennart Meri." Encyclopcedia Britannica. Encyclopcedia Britannica Online. Encyclopædia Britannica, 2011. Web. 14 Feb. 2011. $<$ http://www.britannica.com/EBchecked/topic/376031/Lennart-Meri>.
} 
meant to accomplish or convey a specific goal or point, and had to be situated in the contemporary understanding of the Estonian state and its history. It is this understanding, or rather this constant reworking of that understanding, which is analyzed in this thesis. Whereas the analysis of the national history textbook analyzes specifically the narrative constructed, the analysis of Meri's speeches focuses on the rendering of this national historical narrative into present-day political aims.

Foremost in the scholarship on narrative construction as a mode of analysis is the idea that narrative research differs from traditional research in matters of purpose (Coulter and Smith 2009). Conventional research strives to discover and verify knowledge about the real world whereas narrative research attempts to portray experience, to question common understandings and common assumptions, and to offer more space for interpretation to the researcher (Coulter and Smith 2009, citing Barone 2001, p. 150). The narrative constructed in a textbook is a reflection of a particular notion of the national memory. It is a recorded version of that national memory which is later used to inculcate the society's youth with the values of the state and a sense of pride for one's homeland. Hobsbawm (1997) cynically asked and answered "Why do all regimes make their young study some history at school? Not to understand their society and how it changes, but to approve of it, to be proud of it, or to become good citizens of the USA, or Spain or Honduras or Iraq” (p. 357; cited from Low-Beer 2003, p. 4). But what perhaps also comes across as well as pride in one's national identity are those factors related to identity construction above, namely nationalistic or militaristic securitization and dehumanization of a proximal Other with whom one will likely continue to contend, in daily life as well as in the constant resituating of one's Self within society.

Hobsbawm, in the introduction to the seminal work, The Invention of Tradition (1983), wrote that "It is the contrast between the constant change and innovation of the modern world and the attempt to structure at least some parts of social life within it as unchanging and invariant, that makes the 'invention of tradition' so interesting for historians of the past two centuries” (p. 2). This contrast is exactly what this study attempts to highlight. The tradition invented within a textbook, that which is unchanging and invariant, is set against the constant change and innovation necessary in real time for a real head of state. What makes this study's approach interesting is the relationship between the two objects of study: the narrative of one 
static text against the constant change of the political landscape from which that static text had at one point evolved.

Any two constructions of a national narrative will differ. Those presented by the textbook and contemporary government rhetoric will differ perhaps greatly and in important ways. The textbook's social function has been said to be similar to that of government policy documents (de Castell, 1991, cited in Crawford (a) 1993). This contextual situation seems apt: The textbook is perceived as a representation of state policy and aspirations translated into a particular narrative of the past through which present and future sequences of events seem like the only logical result of that past (Paabo 2010). Therefore, setting that textbook narrative into the context of state policy as explicitly stated by the head of a government, which is timely and adaptable, will provide an excellent case-study of the dissonance created when two narratives, both from authority and meant for internalization by the citizenry, are processed almost simultaneously. The Estonian case is a good setting for this study because of the unique political developments of the 1990s. Rosser’s (2003) assessment that "social studies curricula are politically pliant tools . . . in the creation of civic identity” (p. 14), as well as the similar conclusions of many other studies, do not account for the lasting effects of the narrative constructed and recorded in the national history textbook on contemporary politics. Next, we turn to the extant literature to provide direction for this study and its methodological choices.

\section{LITERATURE REVIEW}

There is an abundance of literature on what can very generally be called memory studies. The literature most relevant here, though, is that focused on the formalization of history, specifically

its construction and interpretation. Here, the construction of a formal history is operationalized as that constructed for national history textbooks and its interpretation through the professional rhetoric of national political leaders. Therefore, this section reviews studies that focus on such issues as they provide a base and significant direction for this study. Where these previous studies have based findings on an examination of either one of these sources, or an aggregation of many sources including those examined here, in studies of particular public memories, this work examines the constructions themselves and sets one against the other in order to show how 
different messages about a national history can be conveyed simultaneously by sources considered authoritative - the national history textbook and the president of a republic, here an Estonian history textbook used in the middle and late 1990s and Estonian President Lennart Meri. This thesis contributes to the larger literature by its examination of and comparison between two contemporary interpretations of public memory, highlighting the several messages about one national history conveyed through different media.

\section{$\underline{\text { A National History }}$}

The writing of history is a matter of much public concern. "Textbook controversies" have erupted to some extent with each publication, most notably in Japan and, most recently, Texas. So it is little wonder that these textbooks have also been subjects of a prolific scholarship. John Issitt's (2004) study, "Reflections on the Study of Textbooks," offers an excellent review of the issues associated with textbook analysis and the benefits of such studies, pointing out that "when the research focus is on the construction, manipulation and reproduction of power and ideology, textbooks offer rich pickings” (p. 688). Especially since Hobsbawm and Ranger's publication of The Invention of Tradition (1983) and then the establishment of post-communist states, there has been a significant increase in the number of studies on the formal writing of history and of national history textbooks in particular. These studies can be characterized as national, transnational, and thematic. That is, their focus has either been on the national histories of a particular nation, of several nations with a shared past, or of a particular issue such as the treatment of race, class, or gender but also particular personalities across nations or time, though these are obviously not mutually exclusive categories of study.

Those studies most easily categorized as national in character generally trace the particular narrative of the national history textbook over several publications, and thus over time and a changing social and political reality. For instance, examinations of Soviet textbooks and their post-Soviet national counterparts have been an important part of this scholarship. Several exemplary studies have emanated from the post-Soviet space, including studies on Ukraine (Janmaat 2006), Latvia (Abens 2006), and Estonia (Paabo 2010) to name a few in the region. The findings of these studies are set into the context of the nations' pasts and tend to focus on the 
new or resurgent nationalisms and the renewed influence of national languages. Of course, scholarship of this type did not begin with the dissolution of the Soviet Union. As this thesis focuses on Estonian narratives, this literature focused on the post-Soviet space presents issues and modes of analysis especially pertinent for this study.

Low-Beer’s study (2001) of Bosnia and Hercegovina excels in identifying the circular nature of historical narrative construction and interpretation that this study focuses on, though from a different perspective. That study analyzed how the narratives constructed reflect politics and the extent to which those narrative frameworks are building blocks used to construct and create social and political change. This thesis analyzes this same circular process, but focuses on the simultaneity of influences upon audiences presented by two constructions of the same past, only one of which can be characterized as responsive to a changing politics.

Studies of a transnational character are also important guides for this study as they examine the same event, issue, or personality in contemporary times across borders and, importantly, across different societies and cultures. Segesten's (2009) comparative study of how Romanian and Serbian inter-group relations developed in opposite directions is an example of scholarship which highlights one of the foundational principles of this study. That is, Segesten's study demonstrates the very different ends reached by different interpretations of the same past. These studies of the several narratives which develop from a common past all illustrate this point, but Segesten's study does a great job of illustrating the very negative results of particularly biased constructions and interpretations of history while also providing a control against which these constructions can be judged.

Thematic studies divide themselves among the above categories as there must be a place or places in which to set the study. Studies focusing on specific issues like minority representation (Janmaat 2005, 2007) or personalities like Abraham Lincoln in American public memory (Shwartz 2005) also give important background for the present study as these specific components of historical memory provide a useful framework for the deeper analysis of the component parts of the narratives constructed and interpreted in the Estonian textbook and by the Estonian president. None, however, has answered the questions this study asks. None have measured different constructions against one another; rather they either assume one construction is significant enough for study or they aggregate sources and use a best-fit model to identify significance across sources. 
Studies of the Estonian narrative since the recovery of state independence have also been helpful guides as they have identified some common themes to map in the textbook portrayal and to track through the political speeches of Meri. These studies have focused largely on the construction of an Estonian identity; thus there has been a significant focus on reaction against a Soviet-and then Russian-identity (e.g., Bruggemann and Kasekamp 2008) following from the Self/Other dichotomy outlined earlier in this thesis. Other studies have analyzed the historical (Feest 2007) and contemporary (Ehin and Berg 2009) relations between Estonia and the historically powerful regional actors in order to demonstrate reasons as to why Estonian identity construction has developed as such. The integration into the European Union has been a dominating line of inquiry in scholarship as this integration has somewhat butted against the post-Soviet nationalism developed in the early 1990s (Feldman 2001). While each of these studies has provided some direction for the current study, no study that this author has found has examined the textbook construction of narrative as a static representation of a particular political moment, the moment of the textbook's production.

\section{Political Rhetoric as Constructed By and Constructing a National History}

No study has examined the textbook in the way it is examined here, but many studies have examined textbooks for other purposes relevant to this thesis. Few studies, though, have examined political speeches in ways similar to this study; that is, to identify particular representations of a national history and no study has done so against another version of that state's history. That political rhetoric is important for its constructive as well as interpretive capacities to the national historical narrative is evidenced by the inclusion of speeches in many studies examining national memory, narrative, and identity. ${ }^{19}$ One study to explicitly study political speech to identify a changing representation of the memory of the nation was conducted by James Curran (2004). Over the terms of five different Australian prime ministers, Curran identifies a changing portrayal of the British Empire in the representation of Australian history. Though this is the only study found which analyzes political rhetoric in a similar manner to that

\footnotetext{
${ }^{19}$ See Olick and Robbins 1998 and Tileaga 2008, for a review of some materials examining political speech as contributing to mnemonic practices.
} 
used in this study, many other studies have viewed political rhetoric as one component of memory construction as it is widely-distributed and from a source recognized as an authority.

This literature review has demonstrated that there is basis for both objects of study in the scholarship and that no study has analyzed these objects from such a comparative perspective. Rather than examining the same event, issue, or personality across time, this study examines the same time period to identity the different constructions of the same history propagated contemporaneously, a goal neither defined nor accomplished to date. While some discrepancies are, of course, assumed to be manifest in other studies compiling different sources, this thesis is meant to portray in stark contrast the different narratives presented simultaneously by the authoritative but static text and the authoritative but ever-changing political rhetoric of the president of the republic, the head of state and symbolic leader of the nation.

\section{METHODOLOGY}

This section details the methodology used in this study. The goal of this study is to answer the question: To what extent and in what ways will the historical narrative presented in a national history textbook lessen or even cease in its effectiveness as a tool of socialization into the state given a changing political reality? Analysis of the history textbook is based on interpretivist approaches to narrative analysis, mapping the narrative constructed within the textbook. The basic lines of the constructed narrative are drawn out of the story presented in the text and organized into coherent and evidence-based assertions. These assertions, when drawn out and organized in this way, appear as the spine around which the history presented in the textbook develops. Analysis of the changing political reality is accomplished through an analysis of the political rhetoric of Estonian President Lennart Meri over the duration of the time period in which the textbook under study was being conceived, was in production, and was in use in Estonian public high schools_-from approximately 1994 through the first half of 1999. President Meri's speeches are not, of course, organized in the same way as the textbook. So analysis of the speeches in the same manner would yield little. Analysis of the speeches using the narrative assertions of the textbook, however, provides a standard against which to judge many different speeches over time, speeches on a variety of topics and to a variety of audiences. It is 
demonstrated that the use of these methods provides the best measure of these different mediums of narrative. The formalized construction of the Estonian historical narrative presented in the textbook is used as a baseline narrative for the interpretations of the Estonian narrative presented through Meri's speeches. Over time, the president's interpretation of that narrative reflects changes in the political and social reality impossible for the static production of the textbook to reflect.

\section{Analyzing the Textbook}

The Estonian national history textbook under study is History of Estonia, written by Laur, Lukas, Pajur, and Tannberg. The version used is an English translation of the second edition of that text. The original edition of this History of Estonia was published in 1995, the second edition was published in 1997, and the translated copy analyzed in this study was published in 2000.

An interpretive approach has been chosen because, contrary to the quantitative or positivist approaches in political science, the interpretive approach is not interested in converting data into numbers, but rather wants to extract the meaning as it is, couched in its original form of expression (Segesten 2009, p. 15). That meaning is carried by the narrative of the history textbook which is sometimes referred to as the descriptive author's text and is, more generally, the subtext of the text. It provides a context in which to read of and transition between the historical events. This mode of analysis "looks for particular connections between events" (Richardson 1990, p. 13) because it is the connections between the individual events presented which give the various events their meaning. The text is the main body of evidence for this study, though the illustrations are not discounted entirely. The power of the image over the text has been confirmed as greatly improving the pedagogical quality of textbooks (Segensten 2009, pp. 26-27) because of the concentrated and concise forms of transmissions of information they allow, the concrete representation of narratives presented, and because they stimulate both verbal and non-verbal memory processes that improve mnemonic performance (Levin and Mayer 1993, 98-99). Therefore, these illustrations will be accounted as complementary to the textual 
narrative. Instances of dissonance between the textual narrative and the connotation or even subject of the illustrations will be especially noted.

The general direction of the study follows from what Frederick Erickson (1986) has said makes a good interpretivist analysis of a text. Some generic questions found to have been applied to textbook content in academic studies by Jason Nichols (2003) have also shaped this study. Lastly, and importantly, the analysis has been shaped by the extensive literature on the construction of national identity and the Estonian experience.

Erickson's description of the means by which a good interpretivist researcher should analyze a text was summarized in an article on the construction of narrative using literary elements by Cathy Coulter (2009, p. 587), a scholar working in education inquiry. The good interpretivist researcher reads and rereads the text as a whole and generates general assertions by inductive means. The researcher then assembles data that confirms as well as that which seems to disconfirm each assertion and examines extreme cases for how they shed light on patterns in the text. The evidence is weighed and those assertions which do not stand up to this process are discarded or redefined according to the data. The assertions that have survived are then placed into a system of organization and a vignette is constructed demonstrating the truth of the assertion in narrative form, framing the assertions and vignettes in interpretive commentary with general patterns and particular data. This study lays bare the assertions and contextualizes each only to the extent necessary to establish relationships among them in order to apply these assertions to the analysis of President Meri's speeches.

The general questions Nichols found to have been applied to textbook analyses relevant for this study have to do with textbook content in relation to recent academic research, recurring characters or events and the extent to which each forms part of a core national memory, values the authors appear to think important, and sufficiency of depth of treatment of the various events and issues. Each of these questions guides the analysis, though none was used as the sole basis for a reading of the text; rather, they served to frame themes presented below and refine assertions once drawn. Importantly, it is a fact that those themes found in the scholarship on collective memory, identity construction, and the Estonian experience have influenced this analysis. That influence has both positive and negative aspects for the thesis. Positively, cognizance of those elements identified as significant to narrative construction is useful so as to situate the study in an established framework. Negatively, because “Texts about identity do not 
reveal but produce identity” (Kuus 2002, p. 94). This study's identification of elements of narrative construction have been shaped by established definitions of these concepts of narrative construction; thus the analysis of the textbook may tend to analyze predominantly from those modes. This is not to suggest that this study will analyze exclusively from those established modes. It is merely meant to identity and guard against a potential bias in the research.

The positive, here, far outweighs the negative. The scholarly literature giving direction to this study has identified several themes which are likely to manifest themselves as part of the textbook narrative as well as within Meri's speeches. These have already been touched upon in the Theory section. The general themes from the literature which have guided the analysis of this textbook and the narrative therein are (A) the securitization of an Estonian identity—and along with it notions of ethnic origins and the Estonian land itself, (B) the Western orientation of an Estonian identity—and with it positive feelings toward democratization and the liberalization of the economy, (C) the Northern orientation of an Estonian identity, and (D) the Estonian identity as the antithesis of the Soviet identity. These themes represent where much of the scholarship on Estonian identity is situated and are themes likely to appear as part of the narrative of the textbook; as such they will be given due attention in the next chapter. These themes will be explicitly examined in the analysis of the textbook and will help refine the final assertions presented. It is those assertions which will be used as the standard measure across time and across speeches.

\section{Analyzing the Speeches}

The assertions drawn from the textbook narrative that stand up to the warranting process, form the spine of the textbook history. These assertions also, when read against the president's speeches over time, reveal a changing interpretation of the national narrative as time progresses and, presumably, the political and social reality on the ground changes. Of course, this thesis can only definitely state at its conclusion that President Meri's interpretation of the Estonian historical narrative changed over this time period. However, President Meri's stature at home and abroad makes his, at least, a profoundly respected voice of and for Estonia. Further, that this one man's interpretation of the national narrative changes over time is important because of his 
position as the head of state. The political consequences of his rhetoric would have weight, though they would not be the end of any conversation. In combination, President Lennart Meri's background and position in the country's political workings make his an important voice to study the political realities as well as aspirations in Estonia over the time period under study.

As stated, the original edition of this History of Estonia was published in 1995, the second edition was published in 1997, and the translated copy analyzed in this study was published in 2000. Therefore, the relevant years for study of the changing political environment in Estonia, as operationalized through President Meri’s speeches over this time period, covers the years when the textbook was being developed, produced, and put into use in Estonian public schools. The years of study, then, are from approximately 1994 through the 1998 school year, thus into 1999. Of course events predating this period will have an effect on both the textbook narrative as well as the interpretation represented in the president's speeches. However, it is the moment of formalization of history in the History of Estonia analyzed here which is of significance. How previous events are resurrected at a later moment in the popular memory is only relevant, for this study, in its influence on President Meri's speeches, made in real time and responsive to that popular memory.

The speeches given over this time period were accessed from an online government archive holding all of the presidents' speeches. Each was read looking specifically for mention, however subtle and in whatever light, of the assertions drawn from the textbook narrative. Not only were the texts of the speeches analyzed, but also the time, place, and audience of the speech was looked to for clues as to just why the text of each speech was shaped as such, again specifically looking to the assertions drawn from the textbook. As stated above, the themes drawn from recent scholarship will shape the assertions, but will not be used in themselves in an analysis of the speeches as they do not represent a unitary narrative but rather the narrative interpretations of the individual scholars at various times. Those themes will recur in this study after the analysis as part of a discussion on the larger public discourse likely responsible, in addition to new or changed political variables, for Meri's changing interpretation of the Estonian historical narrative. These themes represent more recent trends in Estonian politics and society than those present at the time of the textbook's actual production and will be looked to in order to explain shifts in Meri’s rhetoric. 
The methodological choices of this study have been made because of the particular goals of this thesis: to set a static construction of a historical narrative into a real time political context. No study has approached this subject as is done here, though other studies have approached historical narrative as constructed and presented in textbooks and political rhetoric. The literature on textbook constructions of narrative is large and did provide much direction for the study as the approach used combines the deconstruction of narrative, some general questions following from more quantitative research, and some avenues of inquiry based on the literature on Estonian memory and identity. The methodological choices made about the analysis of the speeches were largely this author's own, though theoretically influenced by previous studies. Here, the speeches are analyzed according to assertions drawn from the textbook analysis. This second-level analysis is a contribution of this study as the narratives constructed and interpreted in the textbook and speeches, respectively, are judged against one another rather than some other measure. This was done because, where other studies' goals are to draw conclusions from the narratives analyzed, the goal of this study is to highlight the several narratives simultaneously presented to society and demonstrate the dissonance of message resulting from those several narratives. As time progresses and politics change, these two presentations of the national narrative will diverge. The methodological choices described above were done so to best capture the ways and extent to which this divergence occurs. Thus, a relationship between a tool of socialization into the state (the textbook) and an authoritative interpretation of just where that state is and hopes to be can be identified and any changes to in that relationship over time can be mapped. 


\section{CHAPTER TWO: APPLICATION}

The methodology presented at the end of the previous chapter provides the means to this chapter's end: an analysis of the responsive interpretation of the national historical narrative represented in President Meri’s speeches against the static historical narrative constructed for the nation's youth in the national history textbook. As noted at the end of the last chapter, this chapter is meant to identify and map a relationship over time. To realize that end, assertions drawn from the textbook narrative of Estonian national history are first presented; both the assertions which stood up to the warranting process and those which were not sufficiently supported and the reasoning for inclusion or exclusion are given. Next, the assertions which did survive are organized to best scrutinize the president's speeches for specific interpretations of historical narrative and the analysis of these speeches is provided. Finally, narrative analysis of the distinct speeches is set into the political and social context of the times the speeches were given to identify the reasons for a changing interpretation of historical narrative than that formally constructed at the time of the textbook's production.

\section{NARRATIVE CONSTRUCTION: TEXTBOOK ANALYSIS}

Analysis of History of Estonia according to the methodology chosen yields several basic assertions. These basic assertions are the clear and concise end of an analysis which is necessarily complex because of the particular methodological demands of this study. The four assertions which are the result of this narrative analysis are as follow:

(1) The Estonian people are an ancient, ethnically constituted people. 


\section{(2) Rule by foreigners has been a dangerous impediment to a free and sovereign}

\section{Estonia.}

\section{(3) The fight for freedom by the Estonian people is an age-old fight against foreign}

rule.

\section{(4) The strength and perseverance of the Estonian people will always win the day, eventually.}

As mentioned, these four assertions are the end of a complex analysis. They represent the refinement of earlier assertions drawn from the text and given direction by the relevant literature on Estonian identity and memory politics as well as that on narrative analysis itself.

Analysis of the narrative began with a thorough reading of the textbook. Notes were taken about the general drive of the story being presented as well as anything that immediately stood out from the surrounding text. ${ }^{20}$ Next, the text was reread using these notes as first attempts at general assertions and gathering data supporting and that which seemed to argue against each. The text was also analyzed in subsequent readings using something more akin to quantitative analysis by paying special attention to the number of paragraphs and pages given to particular subjects or certain representations of events and personalities ${ }^{21}$ as well as by taking note of the illustrations and how each complemented or frustrated the presentation of events in the text. ${ }^{22}$

From these early attempts at narrative analysis of the textbook were drawn early renditions of the four assertions presented above as well as vague beginnings of assertions about Estonian soil itself as a predominant drive of the narrative and a preoccupation of the text with modes of production and a strong pro-capitalist and pro-privatization bias. These assertions are included to some extent in the four assertions presented, but sufficient evidence wasn't found to set either out as an independent drive of the narrative presented in the history textbook. The idea that Estonian soil is important to the history of Estonia within the narrative of the textbook

\footnotetext{
${ }^{20}$ For example, a note was taken about section headings suggesting differing presentations of foreign rule. Section IV is entitled "Swedish Rule" and deals with the rule of Estonia by Sweden, while the very next section, V, is entitled "Under Russian Rule" and deals with rule of Estonia by that foreign power. That the Russian rule is represented in this heading as oppressive-because of the word "Under" and lack of the same in the heading about Swedish rule-jumped out as important, and seemed all the more so because of the extensive scholarship of the 1990s dealing with the Russian threat to Estonian identity and security, generally (e.g., Noreen and Sjostedt 2004). ${ }^{21}$ Here, the most notable examples are of the treatment of battles to hold or win back Estonian soil from a foreign invader and of the Estonians who participated and led in these battles. These are primarily found in Sections VII, VIII, and IX, all of which are about the "Ancient Fight for Freedom."

${ }^{22}$ One photo which supports the surrounding text as well as the narrative assertions dealing with foreign rule has the caption, "One occupation replaced by another," and is a photo of the new occupation force changing the street signs.
} 
influenced how the second assertion was refined and codified: though most of the assertions mention the Estonian people, the second assertion has been written using the phrase, "sovereign Estonia," to denote the land itself as an object of importance. The pro-Western systems bias suggested by scholarship about the rebirth of the Estonian state does come across in a reading of the textbook, but the data provided by the textbook doesn't provide the evidence necessary to include this drive as a significant part of the narrative of the textbook. Rather, the focus is on the long-past, on the Ancient.

One significant contribution of the more quantitative approach of this research comes from an analysis of the amount of the textbook devoted to various time periods. Specifically, half of the book (approximately 160 pages of approximately 320 pages) is devoted to the time before "The Era of National Awakening " (Section VI), which itself begins about half a century and 40 pages before Estonia could "be considered as an independent state, though occupied by foreign forces” (p. 210). This organization is made significant by the repeated mention of the Estonian state, even from "The Ancient Times" (p. 9). The first line of the first section, in fact, reads "The period from the arrival of the first inhabitants to the loss of ancient freedom at the beginning of the thirteenth century AD is called the Ancient Times” (p. 10). That an Estonian state didn't develop in these ancient times is attributed to "new groupings [like Kievan Rus, which] could raise larger military units” (p. 30). Thus, the Estonian people were faced with invasion from the earliest times when neighbors could unify in any real numbers. Of course, language suggestive of today's state as the logical end result of history for a people is to be expected of any national history. It must still, however, be pointed out as an important drive of the narrative of this national history textbook.

This focus on the ancient is not the only point to this line of argument, however. The period of independent and sovereign statehood from 1920 to $1940^{23}$ is given about 40 pages, which gives a broad overview of domestic policy and politics, foreign recognition, and the Great Depression. The period of Soviet rule, to contrast this somewhat, from the end of World War II through the mid-1980s (the next section begins with, "by 1985, the international and economic cul-de-sac of the Soviet Union were obvious” [p. 307]) is given only about 35 pages. That such a recent and undoubtedly important historical period is given such comparatively little space gives insight into the larger narrative drive of the textbook as a whole. It suggests an especial attempt

\footnotetext{
${ }^{23}$ These are the dates given in the particular section discussed.
} 
to distance the conception of Estonian history from this most recent occupation. That this seems to be the case in the textbook construction of the Estonian narrative follows from what is to be expected given the recent scholarship on Estonian identity and narrative.

Those general themes suggested by recent scholarship, including this distancing from the Soviet version of Estonian identity, will now be detailed as each helped to construct and refine the four assertions mentioned at the start of this chapter.

(A) The securitization of an Estonian identity—and along with it notions of ethnic origins and the Estonian land itself. This theme of recent scholarship from what can broadly be defined as memory politics is a prevalent drive of the textbook narrative as this securitization can be seen through each of the four assertions drawn from the textbook. Each assertion can be read as an expression of this theme, which has been a prolific theme of the scholarship on Estonia itself. The Estonian narrative of the textbook, however, didn't support the objectification of the Estonian land. Rather, the textbook narrative gave much more weight to the Estonian people fighting for the state as an idea. That this state has geographical boundaries isn't given much attention in the textbook. In fact, the first mention of "ethnic Estonians" reads, "Some pockets of ethnic Estonians were preserved in northern Latvia until the nineteenth century” (p. 25). The borders of what the authors call Estonia are quite flexible over the majority of the history presented and this may account for this attitude. It is the people that make an Estonian state rather than the land. Thus, it is an Estonian identity which needs to be secured. The need for physical security of what is the Estonian state today seems to be directed at the security of the Estonians as such. Still, notions of ethnic origins and the securitization of identity are by far the most prevalent themes from scholarship found in the narrative constructed in the textbook.

(B) The Western orientation of an Estonian identity — and with it positive feelings toward democratization and the liberalization of the economy. This theme was found to be somewhat important to the textbook narrative, though, as stated, not to the extent necessary to identify it as a distinct assertion and therefore a driving aspect of the narrative. Relations with the West are portrayed in a positive light, but the focus of the narrative is very obviously Estonia itself. In discussions of foreign powers, it is clear that western countries and Estonia's Nordic neighbors are conceived differently than either neighbors to the east (Russia and the old Soviet Union) or 
the near west (Germany). In the section on the first period of independence, the text makes this distinction clear: "In the years of independence the number of cultural contacts with other countries increased and Estonian culture got rid of remaining German or Russian influences. Nordic, English and French cultural orientations became dominant” (p. 248). This desire for association with western culture is even tempered in the textbook portrayal with an Estonianness - the authors relate a slogan from the interwar, independent Estonia, and follow it with an explanation: “ 'Let’s be Estonians, but let’s also become Europeans!' expressed the need to get rid of the one-sided Russian and German cultural influences and to find connections between Estonian national culture and that of western Europe” (p. 199).This language suggests that an independent Estonia should choose these western orientations rather than being subjected to the old German or Russian influences. At least this is the message one reads from the textbook narrative.

There is some mention of private property and ownership, but these are generally not the point of the sections and don't significantly affect the text's reading, so were not included in the narrative assertions. In the sections where this ownership idea is the focus of a section, what is gleaned from the reading is the negative results of the lack of ownership rather than positive results from the ownership. For example, in a section on “The First Soviet Year” (p. 264), agrarian reform is framed in the language of confiscation of the land. ${ }^{24}$

Of the theme of democratization, much the same can be said. Democratization, transition to a market economy, the growth of small business and foreign investment: each is set in the language of development and progress, but the larger focus of the sections dealing with them is elsewhere. Also, and following from the earlier point on space allotted to different time periods, there was little history of the Estonian state to present at the point of this textbook's production. The "Restoration of the Independent Estonian Republic” as well as “The Estonian Republic in

\footnotetext{
24 “... A national land fund was established. This included land confiscated from the church, local government, and people who had left Estonia, as well as land taken from the big farms” (p. 267). This is one example of the characteristic language of the sections relating the Soviet experience, language suggesting a lack of choice on the part of the Estonian people, of "forced" actions.
} 
the years 1991-1997” are both presented with a focus on the positive $\mathrm{e}^{25}$ and with an eye toward rationalizing and legitimizing the young Estonian government’s decisions. ${ }^{26}$

The historical narrative presented in the textbook is very much focused on Estonia and Estonians. The Western orientation suggested by scholarship is not a significant part of this construction of narrative. As this is a national history textbook meant to educate and socialize the nation's youth, this is not surprising, though requires some mention.

(C) The Northern orientation of an Estonian identity. This theme largely deals with the Estonians’ Finno-Ugric roots. Northern neighbors were presented in much the same light as western neighbors. With more related histories, however, that light was more focused. Though rule by foreigners is presented as a threat over the course of the book, rule by Sweden is once referred to as the "good old Swedish times" (p. 119) and coming under the rule of Sweden is presented as a decision of the Estonian nobility's “own free will” (p. 114). Again, this theme isn't a predominant one in the textbook narrative, so was only used to refine the four basic assertions presented at the beginning of this section; but in a discussion of the narrative of the textbook, this, too, requires some mention.

(D) The Estonian identity as the antithesis of the Soviet identity. This theme of scholarship is one prevalent in the textbook narrative. Perhaps rather than an antithesis to the Soviet identity, however, the textbook narrative simply portrays the Soviet experience very negatively—and rather frugally ${ }^{27}$--and keeps the history of Estonians more broadly focused than simply on the fifty years of Soviet rule (which undoubtedly shaped the perspective of every generation of Estonians raised in that system). This theme, like the first theme presented, affected the final presentation of the assertions as the great regional historical power, Russia (including in its

\footnotetext{
${ }^{25}$ For example, the building of a constitutional state (p. 316), transition to a market economy (p. 316), and the withdrawal of foreign military units (p. 317), as well mention of the fact that non-citizens can participate in local government elections (p. 318).

${ }^{26}$ For example, in the next to last section, “The Estonian Republic in the years 1991-1997," the textbook addresses the citizenship laws by saying, "the law of citizenship adopted in 1995 regulates the relationship of non-citizens with the Estonian Republic. Various missions ... and international institutes that have studied the state of human rights in Estonia have not found any considerable violations" (p. 319).

${ }^{27}$ That is, according to the quantitative analysis of the amount of space devoted to different themes, eras, and personalities.
} 
Soviet form) has had such a profound influence on Estonian history, and therefore memory and identity.

Besides these themes which were manifest in the textbook, what is also important to the textbook portrayal of Estonian historical narrative is the way the authors have chosen to end the textbook. It doesn't affect the assertions themselves as they are constructed from the narrative of the textbook as a whole, but it is worth mentioning as this is the final point any reader will take away. The last chapter, entitled "Estonians in the World" relates the legal case for Estonia's occupied status as well as describes where, physically, Estonians are throughout the world and includes a map. This obviously continues the focus of the book on the Estonian people and shows a larger population than that currently on Estonian soil. It also, however, sidesteps a discussion of just where Estonia is domestically, especially as regards the Russophone population and other minorities. Mention of the language laws as well as the short time period covered since re-independence no doubt justified this choice to the authors. Still, after reading the textbook and looking back to notes on the scholarship of the time period, this treatment makes the issue conspicuous by its absence instead of a domestic issue capable of being presented in a few paragraphs at most.

The assertions following from this mode of analysis are distinct, though obviously very related. The Estonian people are an ancient, ethnically constituted people. This is the first assertion of the narrative presented by the Estonian national history textbook analyzed, History of Estonia. It is an assertion driving the narrative and necessary to confront in order to understand the assertions to follow. Rule by foreigners has been a dangerous impediment to a free and sovereign Estonia. The ancient history of this people and, to a lesser extent, their homeland, have for all but about forty years been subjugated to a foreign power, always a larger regional political power. The fight for freedom by the Estonian people is an age-old fight against foreign rule. It is a fight every generation of this ancient people has fought. Only twice in its history has this foreign rule been abolished and today Estonians are winning that fight; though that fight may recur tomorrow and this must be guarded against and prepared for. The strength and perseverance of the Estonian people will always win the day, eventually. Over the course of history, the Estonian people have always fought against the foreign oppressors. Their fire and patriotism will carry them to freedom if that fight for freedom should need to be fought again. 
Independence was achieved after World War I and independence has been recaptured following the rule of the Soviet Union. Today, the fate of the Estonian people is in their own hands, they are modernizing to the standards of the most advanced countries in the world- those of the West, and are a sovereign state and part of Europe. This is the narrative constructed in the History of Estonia analyzed herein.

Rather than analyze President Lennart Meri’s speeches from this brief vignette which connects the assertions, the four basic assertions drawn from the narrative will be used to analyze the speeches for changing interpretations of each, and thus, of the historical narrative, over the time period the textbook narrative was being produced and was actually in use in Estonian schools. Thus, each assertion needs to be explained more concretely and more coherently than simply leaving the reader to piece together a conception of each from the description of the process of analysis related above.

\section{The Estonian people are an ancient, ethnically constituted people.}

The first assertion arising in a close reading of this textbook is that there is a native Estonian population which has lived on today’s Estonian soil since “The Ancient Times” with the arrival of the first inhabitants-i.e., the first Estonians. Throughout the textbook, there are instances of other peoples migrating into the land inhabited by the native, "ethnic Estonians.” There is also repeated mention of these foreign peoples assimilating into the Estonian culture and seemingly, gene pool. Not to stand completely without contradiction, however, mention is made of the centuries during which "the natives merged with the newcomers" (p. 25). The majority of instances found in the textbook, though, cite the newcomers assimilating into the Estonian camps, "soon adopt[ing] the local language, customs and ways of work” (p. 115). This important piece of the narrative portrayed in the textbook is intertwined throughout the textbook with notions of threat to Estonians from foreign influences.

These foreign influences are manifested in terms of language to a significant extent. The Estonian language is a topic taken up early in the text, dating the language back to the ancient times and even describing many Russian words ending in -va, like the River Moskva, as being Estonian in origin. The tendency here, too, is to frame the language as something ever-under 
attack. Especially in periods of Russification or Germanization, the passages involving language are adversarial with respect to the use of the foreign language within Estonia.

\section{Rule by foreigners has been a dangerous impediment to a free and sovereign Estonia.}

The notion of threat from outside is one prevalent in the literature discussed in the previous chapter. Rule by a foreign power was accompanied by the imposition of the language of the invaders, at least for administrative functions. Importantly for this study, the authors of the textbook acknowledged that "The hardest blow from Russification was to the educational system of Estonia” (p. 180). Also, for most of the history presented in the textbook, the elites in Estonian society, those most likely to affect government and influence society, were foreign—at different times, German, Swedish, or Russian.

Treatment of these foreign rulers in the textbook differs along cultural lines. The German rule is portrayed negatively, generally. Importantly, though, many instances describing German rule or influence are placed into the context of the "Ancient Fight for Freedom" (p. 38) in Estonia, an age-old fight which is presented in the textbook as arising every few centuries in some form, culminating in the independence of the 1990s, suggesting that this historical animus may be falling away. This is especially likely the interpretation one will glean as entry into the European Union is set in very positive and progressive terms - and as Germany, of course, is a leading member of that Union.

The treatment of Swedish rule ${ }^{28}$ is in marked contrast to the portrayal of Germany and especially to that of Russia. Though the Estonians always "finally" or "ultimately" were forced into either compromise or surrender to German or Russian forces, rule by these groups is always put in the language of subjugation to another. Pointedly, one passage states that "Suspiciousprobably not without reason — of local Baltic Germans, Estonians often undertook long journeys to Stockholm” (p. 118) to present petitions to Swedish authorities. This treatment, as stated above, does not warrant a significant change to the assertion as the language used regarding Sweden does refer to the Estonians coming under Swedish rule "of their own free will” (p. 113).

It is primarily Russia that is seen as the looming threat to Estonia. Throughout the textbook, passages involving Russia generally frame events so that Russian ambitions on Estonian territory are perceived as the cause. Of course, this language is stepped up in the

\footnotetext{
${ }^{28}$ That is, the treatment described above (e.g., "good old Swedish times”).
} 
sections about Soviet Russia, but the language is much the same throughout the entire history presented in the textbook. In fact, similar language pervades the textbook, dividing the narrative along two frontiers. First, Germany and Russia are portrayed for the most part as oppressors of the Estonian people, historically having designs on the land and the cheap labor potential of the peasantry. Russia is that power to the east which must always be guarded against. The language used in the textbook constantly reiterates that Russia has ambitions for Estonia and the Baltic states, even today. ${ }^{29}$ The portrayal of Germany in this light is interesting because of the second frontier presented by this narrative, the Western divide.

Throughout the textbook, "Western" practices are consistently placed into a favorable light. Even the actions of the Allies in not preventing the annexation of the Baltic States through the Molotov-Ribbentrop Pact is contextualized positively, saying the western nations were in no hurry to satisfy the Soviet Union's demand for concessions in the Baltics for its entry into the war on the side of the allies (p. 259). Western economic practices are presented as progressive though here, too, the foreignness of the German, historically, mitigates this: "Those Estonians who managed to become owners of shops or independent craftsmen were considered successful. At the same time, those Estonians who were better off tried to behave like Germans in every way and were ashamed of their origin” (p. 163). Germanization is thus portrayed as a betrayal of one's Estonian roots while Russification is portrayed as a completely forced process. Instances of Estonian cooperation with either Germans or Russians are presented as expedient at the time and merely as passing alliances. But despite some light and even positive language about foreign powers, it is clear that a primary driver of the narrative is captured by this basic assertion.

\section{The fight for freedom by the Estonian people is an age-old fight against foreign rule.}

This Ancient Fight for Freedom has already been mentioned. Nonetheless, as over half the textbook is set before what the textbook's authors termed "The Era of National Awakening," its place in the construction of this Estonian historical narrative merits more attention. For over 150 pages, the reader learns of the very long struggle of those people who predominantly made up the peasantry of what is today, Estonia, to remain a culturally distinct people. That this small area existed in between much larger and much more unified state structures placed it on the defensive for the vast majority of that history. Repeatedly throughout the textbook but especially

\footnotetext{
${ }^{29}$ P. 319: "Various political forces in Russia have not lost hope of restoring their former empire."
} 
the earlier sections, transitional phrases set up a fight that will be resolved some day if only hope can be held out. For example, “The brave resistance of their ancestors inspired the Estonian people to continue the fight for freedom and independence for centuries to come” (p. 52). Today, the fight is being won, but it is due to the dedication of centuries fighting off a foreign yoke. This thread of the Estonian historical narrative presented in the textbook is obviously very much involved with each of the other assertions. That the Estonians are a people, that they have been ruled by foreign powers and not their own Estonian leaders, and that this fight for freedom is as old as themselves are each important pieces of an identity puzzle made personal by the next assertion drawn from the narrative presented in the textbook.

\section{The strength and perseverance of the Estonian people will always win out, eventually.}

This is the most consistent and the most prevalent of these threads of narrative presented in the textbook. This is the assertion drawn from the text as a whole, in which Estonia is depicted as a small, struggling nation, always under threat from larger, more powerful actors, but whose people keep up the fight and eventually, through perseverance, strength, and bravery, win out against those larger powers and establish (and then re-establish) the independent state of Estonia, for which this history textbook was written. This element of the narrative is presented in nearly every section of the textbook. Large sections are dedicated to resistance forces or battles where Estonians either were victorious or came close. Transitional passages evoke Estonian ancestral heritage and always placing the desire and fight for freedom from subjugation, specifically by rulers from outside of Estonia, as an ideal and a historic priority of the Estonian people. Even instances of defeat can be turned into something greater: "The regime in power had seemingly eliminated the resistance movement. In fact, the relative silence that followed was a period of preparation for the resistance of 1987, which grew into a general resistance in 1988” (p. 300).

Now we turn to an analysis of President Meri’s professional rhetoric over the time period to measure to what extent and in what ways the interpretation of a historical narrative will change, thereby measuring, qualitatively of course, to what extent and in what ways the historical narrative presented in a national history textbook lessen or even cease in its effectiveness as a tool of socialization into the state given a changing political reality. 
NARRATIVE INTERPRETATION: SPEECH ANALYSIS

President Lennart Meri served as President of the Republic of Estonia from 6 October 1992 to 8 October 2001, a period which covers the entirety of this textbook’s conception, production, and use in the Estonian public school system. This thesis has focused its analysis on the years 1994 through the first half of 1999 in order to get a range of historical narrative interpretation from the textbook's conception through the end of the 1998 school year as a newer textbook became available for the next school year. The speeches analyzed are those of a charismatic and nationally-minded head of state, a historian of Finno-Ugric peoples, and the son of a diplomat. Each speech over this time period was directed toward a specific audience, was meant to accomplish or convey a specific goal or point, and had to be situated in the contemporary understanding of the Estonian state and its history. It is this understanding, or rather the constant reworking of that understanding, which is analyzed here. Analysis of these speeches will proceed chronologically, though not speech by speech or strictly year by year, and will identify congruencies and deviations over time between the individual speeches and the narrative found to have been constructed for the national history textbook as organized into assertions above. The assertions drawn from the textbook and described above will be the standard against which the interpretations of historical narrative as presented in the speeches will be judged. The progression of time will organize this section rather than the assertions themselves, though the assertions remain the measuring stick of change. Each speech is a snapshot of an understanding of the historical narrative at that time. Because, however, we must provide for the place and audience in any analysis of speeches, it is the general trend over the course of speeches which is of especial interest here.

The earliest speeches under study here are from 1994 and 1995, the time in which the textbook was originally conceived and produced. Across these speeches, especially when compared to speeches later in the decade, there is the constant presence of the recent Soviet experience. President Meri tended to use metaphors which conjured Soviet era or Cold War images in order to emphasize some message. For example, in December of 1994, Meri spoke of a metaphorical flame that could be seen "clear across the Gulf of Finland, a flame that grew to be a beacon of hope through the long, dark and cold years behind the Iron Curtain” (Meri, 5 Dec 
1994). This same approach was used in October of 1994, evoking the memory of mass deportations and mass emigration, ${ }^{30}$ to express empathy for the loss of a Swedish ship, named Estonia, and its crew. This use of the recent and dark past of subjugation to a foreign power clearly seems to be the result of an interpretation of the national narrative similar to that presented by our textbook, namely assertion $2^{31}$ but also $3 .{ }^{32}$ These references made in these early speeches are used to affect a certain dark mental imagery in the audience.

The early speeches also evoke the Soviet past to rationalize the poor present state of affairs. For example, when so much was made of the citizenship and language laws of the newly re-independent Estonia, Meri attributed the pettiness to "arbitrary behavior by small bureaucrats [who] should have been thrown out together with Soviet rule and cannot be accepted in independent Estonia” (Meri, 17 May 1994). Throughout 1994, especially, mention of this recent past is often and always in a very negative and personal light.

As time passes - and either the political needs required or the memory was in fact changing, or both—evocation of this past is set in more neutral terms. The references also change to show a lingering conception of a dichotomous Western versus Eastern orientation: "If during the Cold War, the fate of Berlin became a kind of litmus test for Western security, then the Baltic states play that role now" (Meri, 19 October 1995). This reference to a litmus test is acknowledged but President Meri also uses the opportunity to get away from that perception of Estonia:

Estonia will not wish to limit its role to that of a litmus test, we would be glad to be the catalyst for new all-European security system. Please do not take these words as mania grandiose of a small state, our aspirations proceed from our historical memory, from our worry for the future of Europe, from our wish that Europe should survive” (Ibid).

This language is characteristic of the late 1995 and early 1996 speeches, wherein Meri hearkens back to "historical memory" without giving evocative details, but rather uses the moments to speak of the experience of a state which has "belonged in Europe for 700 years already" (Ibid). This evocation of a long history is one point which remains in Meri’s speeches throughout his

\footnotetext{
30 "As an Estonian I can avouch to you that we have not suffered a loss claiming so many victims since the March mass deportations in 1949. We have not suffered a loss at sea claiming so many lives since the great September wave of flight by boat in 1944. (Meri, 2 October 1994).

${ }^{31}$ Rule by foreigners has been a dangerous impediment to a free and sovereign Estonia.

32 The fight for freedom is an age-old fight by the Estonian people against foreign rule.
} 
presidency. In diverse situations, from sympathetic speeches ${ }^{33}$ to those on international law, ${ }^{34}$ Meri cites the ancient vintage of the peoples of the Baltic littoral and of Estonians, in particular. This is directly in line with the first assertion ${ }^{35}$ and doesn't change throughout the period of analysis.

Also beginning about this time, there is a call in the speeches for a normalization of relations with Russia ${ }^{36}$ and a treatment of that state as an equal and a friend (though this rather hopeful conception will become less prominent over time). In mid-1996, Meri said, "If I am not grossly mistaken, it is anachronistic, if not also politically incorrect, to speak in terms of sphereof influence, historic territories and such" (Meri, 27 June 1996), suggesting an attempt to "reset" the relationship to use the language of the Obama administration's own diplomatic attempt at better relations with Russia. To assuage talk of the older conceptions, those which Meri wished to get away from, he put this new line more directly on a visit to New York with his fellow Baltic heads of state: "As you might imagine, in Vilnius we focused largely on security issues, in particular on the enlargement of NATO and the European Union. We did so not, as you also might imagine, out of fear of the East” (Meri, 25 June 1996).

By early 1997, the language regarding the East was that of mutual experience and positive in outlook. At a meeting of NATO and partner country heads of state, Meri said, I salute the presence here of our Russian partners. Their path to Madrid has been a long and difficult one. I myself have listened to the anti-NATO propaganda which came from Radio Moscow during Soviet times. Therefore I can well imagine the difficult task faced by our Russian friends in breaking these barriers. I am convinced that your presence here today is very important (Meri, 09 July 1997). Meri continued with this line in a later speech, saying that "the use of not only the Soviet Union but also "the former Soviet Union" as political notions or arguments have been sent into the dustbin of history” (Meri, 20 August 1997). The hopeful language of Meri’s speeches in the mid1990s didn't bear fruit for too long as his rhetoric returned to seeing Russia as the East and

\footnotetext{
33 "He served the way Estonian captains have served for hundreds of years, and, up to the very last moment, was loyal to the laws of the sea” (Meri, 2 October 1994). This quote is from the speech about the loss of the Estonia and its crew.

34 "Ever since the establishment of the Republic of Estonia in 1918 we had already been embraced by the fold of European states as a legal equal” (Meri, 3 December 1994).

${ }^{35}$ That the Estonian people are an ancient, ethically constituted people.

${ }^{36}$ For example, Meri 19 October 1995.
} 
something apart: "Estonia is a natural gateway; a gateway between East and West, between North and South” (Meri, 15 March 1999). In this same speech, Meri said that Estonia would “continue engaging Russia and not to give up on Russia” (Ibid), reinforcing the fact that the two states had followed decidedly different paths.

But it is not merely the East with which Meri concerned himself in speeches. There is a constant appeal to the European Union and NATO on behalf of Estonia or the Baltic states as a group (depending upon the audience to the speech) about the advantages of enlargement. In the 1994 and 1995 speeches, this theme is present, but it really becomes conspicuous and, in fact, a predominant subject later in the decade. Meri speaks on behalf of other countries farther east or less developed economically, socially, and especially judicially as candidate countries. In these later speeches, there is a firmer conception of Estonia as a part of Europe and Meri is able to speak to these subjects more than in the brief mentions and appeals found in earlier speeches when, according to Meri, Estonia as a state was “still only just at a voice-breaking age” (Meri, 31 December 1995). But while a European orientation is important, clearly, to Meri's interpretation of the modern national narrative, "historic experience" is never left completely behind, especially to domestic crowds. To the Riigokogu (Estonian parliament) in 1997, he reminded that "Estonia has never left Europe. However Europe has left Estonia. This is our historic experience, this is also our historic obligation and responsibility” (Meri, 8 September 1997).

Analysis of President Meri's speeches over the course of four and a half years from a particular national narrative constructed for the Estonian national history textbook illustrates how different interpretations of the same history can be represented to a public. Using the four basic assumptions drawn from the textbook gives us a good snapshot of a particular political moment, one which is also found to be represented in the speeches of the early 1990s. As time and the political reality progress, though, that snapshot is used to measure just how far an interpretation is from that moment the snapshot was taken and in what ways. Though the assertions were basic derivations of the complex narrative presented in the textbook and, thus, the analysis of the speeches necessarily mapped the changing interpretation of only those basic drives, the distance from textbook narrative to narrative as interpreted in the late 1990s is significant. Now, a brief iteration of the changing interpretations, presented above fluidly, of the basic assertions will give us a better picture of the relationship of each narrative assertion and Meri's interpretation of each over time. 


\section{The Estonian people are an ancient, ethnically constituted people.}

This assertion, regardless of the country's name, is one likely to be found in any national history, no matter the politics from which it is constructed. There must be a historical basis for a people in order to give a coherent identity to the citizens of that state. In 1994, Meri’s interpretation of this assertion of the narrative as presented in History of Estonia is much the same as his interpretation in 1999 and over the entire course of that period. As a proud citizen of that state, and compounded by his responsibilities as a statesmen, there is no reason to expect a changed interpretation of this assertion. Meri recalls centuries of Estonian-ness in various contexts to various audiences over the period and achieves different ends in doing so. No matter the end, however, the underlying understanding of this aspect of the historical narrative remains consistent.

\section{Rule by foreigners has been a dangerous impediment to a free and sovereign Estonia.}

Early in the period studied, Meri's interpretation of this assertion of the narrative analysis is much the same as is written in the textbook. Much language is used to describe the subjugation Estonia has just liberated itself from. Though this assertion is evoked using metaphors and asides to the main conversation, generally, it is a consistent and powerful part of his speeches in the early part of the mid 1990s. As time progresses, rather than speaking to "rule by foreigners," i.e., the subjugation of old, Meri begins to speak of Estonia as a part of Europe, implying an equality with the other members of that Union but rarely mentioning it. This suggests a different interpretation than that printed in bold above and drawn from the textbook. While undoubtedly, Meri would have agreed with the statement written above, the direction Estonia was taking was toward inclusion in a greater body rather than merely defending a renewed sovereignty.

\section{The fight for freedom by the Estonian people is an age-old fight against foreign rule.}

The pattern in Meri’s speeches following from this assertion nearly mirrors that for the previous assertion. Toward the beginning of the time period studied, the fight is prevalent: it was a hard-fought freedom achieved with the collapse of the Soviet Union and Estonians should be proud but not complacent and should continue the fight for an Estonia (even if that fight is merely one of public relations on the international scene). As the years pass and confidence 
grows in a secure Estonian state and a secure Estonian identity, however, this language falls away in Meri's speeches. In its place is the language of a victorious people, a people who have been through great challenges and who may serve as a model or advisor to others in difficult times. The language is one of confidence in the Estonian cause in the later speeches, especially where Russia is concerned in the 1997 and 1998 speeches. In speeches about the European Union, Meri portrays Estonia as a willing and very able mediator between West and East, a knowledgeable agent that has dealt successfully with the East in the past. This assertion sees the most change over time in its interpretation by Meri as the "Ancient Fight for Freedom” can be said to have finally been won, and since, in the current world system, a similar loss of sovereignty to those of centuries past is unforeseeable.

\section{The strength and perseverance of the Estonian people will always win out, eventually.}

This, the final assertion, follows the same trajectory of interpretation over the time period as the first assertion. Again, as a proud citizen and a statesman, there is no reason to assume language other than that presented above. The Estonian people will persevere. This language infiltrates the previous assertion's interpretation for Meri over the years and results in that already noted confidence of tone. As that Fight for Freedom is finally won, this assertion is confirmed, not questioned or in need of refinement, as the years move on.

It must be said that these four assertions drawn and refined from the textbook are not particular to Estonia, of course. Any politician or national advocate faced with running and building a young state, especially one coming from a colonial or otherwise subjugated state, would probably agree that these four assertions would form at least part of the drive of their historical narrative. The Estonian textbook's narrative is little different from many other national history textbook narratives in that way. What makes the Estonian case so interesting is the speed with which this narrative became, at least partially, ${ }^{37}$ obsolete. Over the course of just five years, the historical narrative propagated in the state-issued textbook became irrelevant, at best, and an impediment to the successful implementation of new government aims, though it still remained a functioning tool of socialization in the school.

\footnotetext{
${ }^{37}$ Though assertions 1 and 4 remained basically unchanged over the course of the time period studied, this statement refers to the theory set out in the first chapter of this thesis: i.e., any construction of a historical narrative constructed before being put into use and after any changes, even minor, to the political reality is outdated.
} 


\section{CONCLUSIONS}

This thesis set out to describe the relationship between what is deemed one of the most powerful tools of socialization (the national history textbook) and the state into which the readership is being socialized as time moves and the social and political reality changes. This was accomplished through a narrative analysis of an Estonian history textbook, History of Estonia, and a subsequent analysis of the public rhetoric of the President of the Republic, Lennart Meri over the time period in which the textbook was conceived, produced, and in use in Estonian public high schools. The narrative presented in the textbook served as a baseline historical narrative from which to track a constantly-changing interpretation of that historical narrative over that time period.

From the textbook, four basic assertions were drawn and refined to be written as follows:

1. The Estonian people are an ancient, ethnically constituted people.

2. Rule by foreigners has been a dangerous impediment to a free and sovereign Estonia.

3. The fight for freedom by the Estonian people is an age-old fight against foreign rule.

4. The strength and perseverance of the Estonian people will always win the day, eventually.

These assertions form the narrative drive of the textbook and were used as a snapshot of the historical narrative propagated at the moment of the textbook's production. In the subsequent analysis of President Lennart Meri’s speeches, his interpretation at first was in line with the narrative presented in the textbook but deviated as time moved on.

This deviation can be said to be the product of a larger societal shift, especially in the political echelons, toward a desire for accession to the European Union and NATO. As a small state, Estonia — whether admittedly or no-must associate with larger powers in some direction or face being left out of an ever-more attractive cooperation and internationalization. The East 
carried memories for some and history for others; the West, though, carried hope for a future as yet untried. As talks of accession progressed and goals were set for domestic changes, the reality of joining Europe in more than rhetorical or historical association became more and more attainable and present. Thus, Meri’s public rhetoric deviated from the understanding he demonstrated early in the period under study, and from that portrayed in the textbook, to an interpretation of Estonian historical narrative more conducive to the new aims of the Estonian people as represented by the government and statesmen like Meri himself.

Of course, accession to the European Union was not the only factor affecting Meri's interpretation of the historical narrative. As stated in the "Speech Analysis" section, time itself likely fostered a growing confidence in the Estonian identity and the endurance of this Estonian state. Nor are these two factors the only variables affecting Meri's interpretation of the Estonian historical narrative over the time period discussed. They are, however, very strong influences, one external and one born from within the individual. And as the formation of identity requires a negotiation of self into the outside world and vice versa, growing confidence seems likely a strong factor. Domestic issues, of course, cannot be discounted but Meri's treatment of domestic problems is usually framed in relation to international bodies so it would seem these were given special attention by nearly all the bodies to which he spoke. The prominent themes in the scholarship do appear in speeches, though the fact that each was geared toward a specific audience and with a specific purpose makes an analysis along these lines inconclusive at best. The reasons the interpretation changed are important, of course, but are not the point of this thesis to describe-rather the point is to highlight the deviation over the course of time between the narrative presented in the textbook and the interpretation of the historical narrative. That which is written down is there for posterity but only represents a moment at some point in the past. That which is said aloud (until it is recorded in an archive at least) is almost fleeting but better captures the moment it is said. Both should strive for dispassionate interpretations of history in order that dissonance is avoided in those who read and hear both, even if a few years apart.

That the Estonian people will survive any hardship and win out in any conflict is something no Estonian citizen, let alone politician, would deny. That the Estonian people are an ancient people, too, is something unlikely to cause contention in Estonian political circles. Thus the bookend assertions of the textbook narrative analysis encountered no real challenge based on 
the analysis of President Meri's speeches. The assertions which fall in between those bookends, and which are supported by them as well, however, do respond to a changing political reality. In the early and mid-1990s, the political reality of Estonia was that of a new (re-established) state fighting for a place on the international scene among established powerful regional actors. As time moved on, conditions improved, and confidence grew in an Estonian national identity, orientation toward the West (as expressed through the desire to join the EU and NATO) became an increasingly attractive political alternative, in contrast to mere securitization of the homeland. This trend becomes clear through the analysis of President Meri's speeches. That a politician changed gears over the course of years is not the point, however.

The static construction of the historical narrative presented in the Estonian national history textbook was used in Estonian public schools for the duration of the period of analysis of Meri's speeches. That a textbook narrative is not responsive to the politics of the day is not the point, either. Rather, it is the existence of these two-mere examples, frankly ${ }^{38}$ —of “official” narratives being propagated simultaneously which is the point of this study. The extent to which a student internalizes the narrative presented by his or her textbook is irrelevant. That the student is tested largely from a textbook containing a particular construction of a narrative is relevant. Different interpretations of the Estonian historical narrative presented by an authoritative textbook and the symbolic leader of the nation will undoubtedly, if any thought is given, create dissonance for the receiver of those messages. The negotiation of one's self in relation to the larger national narrative is a necessary step to finding and accepting one’s own identity. Such dissonance may be resolved by a negotiation between the two or by a complete rejection of one or another of these narratives. The latter would be dangerous to any regime's stability. President Meri, in a speech on the first day of school in 1998, told students that to learn about Estonia is "how love of Estonia is born” (Meri, 1 September 1998). That love, depending upon the lean of the narrative constructed in the students' textbooks, may just turn out to be a love for an image of Estonia the state no longer wishes to hold up as an ideal.

\footnotetext{
${ }^{38}$ By this, I mean to say that there are many different mediums for an official narrative of the state. The two presented here are intended to demonstrate that a dissonance will be created and that too much of a lean in any direction can create a confused and potentially reactionary audience in changing political winds.
} 
This page is intentionally blank. 


\section{BIBLIOGRAPHY}

\section{Primary Sources: Textbook}

Laur, M., Lukas, T., Pajur, A., \& Tannberg, T. (2000). History of Estonia. Tallinn, Estonia: Avita. Originally published 1997: Avita.

\section{Primary Sources: Speeches Cited}

Meri, Lennart. 17 May 1994. "President Meri Address to the Diplomatic Corps in Kadroig May 17, 1994.” <<http://vp1992-2001.vpk.ee/eng/k6ned/K6nedeArhiiv.asp>>

Meri, Lennart. 2 October 1994. "The President of the Republic of Estonia At the Memorial Service for the Ship 'Estonia’ Stockholm, 2 October 1994.” <<http://vp19922001.vpk.ee/eng/k6ned/K6nedeArhiiv.asp>>

Meri, Lennart. 3 November 1994. "President of Estonia to the International Conference 'Estonia and the European Union” November 3, 1994.” <<http://vp19922001.vpk.ee/eng/k6ned/K6nedeArhiiv.asp>>

Meri, Lennart. 5 December 1994. "President of the Republic of Estonia at the Commission on Security and Cooperation in Europe Summit 5-6 December 1994, Budapest.” $<<$ http://vp1992-2001.vpk.ee/eng/k6ned/K6nedeArhiiv.asp>>

Meri, Lennart. 19 October 1995. “Address by Mr. Lennart Meri, President of the Republic of Estonia at the Carnegie Endowment for International Peace 19 October 1995, Washington, D.C.” <<http://vp1992-2001.vpk.ee/eng/k6ned/K6nedeArhiiv.asp>>

Meri, Lennart. 31 December 1995. “New Year’s Message of the President of Estonia.” <<http://vp1992-2001.vpk.ee/eng/k6ned/K6nedeArhiiv.asp>> 
Meri, Lennart. 25 June 1996. "Remarks by Mr. Lennart Meri, President of the Republic of

Estonia at the Presentation of the 1996 Institute for East-West Studies Freedom Award in New York." <<http://vp1992-2001.vpk.ee/eng/k6ned/K6nedeArhiiv.asp>>

Meri, Lennart. 27 June 1996. "President of the Republic at the Center for Strategic and

International Studies Washington, D.C.” <<http://vp1992-

2001.vpk.ee/eng/k6ned/K6nedeArhiiv.asp>>

Meri, Lennart. 9 July 1997. "Remarks by the President of the Republic at the Meeting of NATO and Partner country Heads of State or Government in Madrid." <<http://vp19922001.vpk.ee/eng/k6ned/K6nedeArhiiv.asp>>

Meri, Lennart. 20 August 1997. "President of the Republic on the Occasion of Laying the Cornerstone of the Estonian Embassy in Lithuania, Vilnius.” <<http://vp19922001.vpk.ee/eng/k6ned/K6nedeArhiiv.asp>>

Meri, Lennart. 8 September 1997. "President of the Republic at the opening session of the Riigikogu. <<http://vp1992-2001.vpk.ee/eng/k6ned/K6nedeArhiiv.asp>>

Meri, Lennart. 1 September 1998. "President of the Republic on the First Day of School." <<http://vp1992-2001.vpk.ee/eng/k6ned/K6nedeArhiiv.asp>>

Meri, Lennart. 15 March 1999. "Address of the President of the Republic at the Carnegie Endowment for International Peace Washington, D.C., March 15, 1999.” <<http://vp1992-2001.vpk.ee/eng/k6ned/K6nedeArhiiv.asp>>

$\underline{\text { Secondary Literature }}$

Aalto, P. (2003). "Revisiting the Security/Identity Puzzle in Russo-Estonian Relations.” Journal of Peace Research 40(5): 573-591.

Apple, M. (1979). Ideology and Curriculum. Boston: Routledge.

Assmann, J. and Czaplicka, J. (1995). “Collective Memory and Cultural Identity.” Cultural History/Cultural Studies 65: 125-133.

Assmann, A. (2008). “Transformations between History and Memory.” Social Research: An International Quarterly 75(1): 49-72.

Barone, T. (2001). "Science, Art, and the Predispositions of Educational Researchers." Educational Researcher 30(7): 24-28. 
Bennich-Björkman, L. (2007). “Civic Commitment, Political Culture and the Estonian Inter-War Generation.” Nationalities Papers , 35(1): 1-21.

Berg, E. (2002). "Local Resistance, National Identity and Global Swings in Post-Soviet Estonia.” Europe-Asia Studies 54(1): 109-122.

Berg, E. (2007). “Where East Meets the West? Baltic States in Search of New Identity.” In T. Hayashi and H. Fukuda (eds), Regions in Central and Eastern Europe: Past and present. Sapporo: Slavic Research Center, Hokkaido University.

Berg, E. and Ehin, P. (eds). Identity and Foreign Policy: Baltic-Russian Relations and European Integration. Farnham, Surrey: Ashgate. 2009.

Brubaker, R. Nationalism Reframed. Cambridge: Cambridge University Press. 1996.

Bruggeman, K. and Kasekamp, A. (2008). "The Politics of History and the 'War of Monuments' in Estonia." Nationalities Papers 36(3).

Cohen, Sande. (1978). "Structuralism and the Writing of Intellectual History." History and Theory 17(2): 175-206.

Connolly, W. Identity/Difference. University of Minnesoata Press. 1991.

Coulter, Cathy and Smith, Mary Lee. (2009). "The Construction Zone: Literary Elements in Narrative Research.” Educational Researcher 38(8): 577-590.

Crawford, Keith. (2003a). “The Role and Purpose of Textbooks.” International Journal of Historical Learning, Teaching and Research 3(2): 5-10.

Crawford, Keith. (2003b). "Culture Wars: Serbian History Textbooks and the Construction of National Identity." International Journal of Historical Learning, Teaching and Research 3(2): 43-52.

Crawford, Keith and Foster, Stuart. War, Nation, Memory: International perspectives on WWII in school history textbooks. Charlotte: Information Age Publishing, 2007.

Erickson, Frederick. "Qualitative Methods in Research on Teaching.” In Handbook of Research on Teaching, edited by Merlin Wittrock, 119-161. New York: MacMillan, 1986.

Feest, D. (2007). "Histories of Violence: National Identity and Public Memory of Occupation and Terror in Estonia." In D. Darieva and W. Kaschuba (eds), Representaions on the Margins of Europe: Politics and Identities in the Baltic and South Caucasian States. Frankfurt/New York: Campus/Chicago University Press. 
Feldman, M. (2001). European Integration and the Discourse on National Identity in Estonia." National Identities 3(1): 5-21.

Gedi, N. and Elam, Y. “Collective Memory—What is it?” History and Memory 8(1996): 30-50.

Gillis, J. R. (1994). “Memory and Identity: The history of a relationship.” In J. R. Gillis, Commemorations: The Politics of National Identity. Princeton: Princeton University Press: pp. 3-40.

Goldberg, T., Porat, D., and Schwarz, B. “ 'Here started the rift we see today’: Student and textbook narratives between official and counter memory.” Narrative Inquiry 16(2)(2006): 319-347.

Hobsbawm, E. (1983). “Inventing Tradition.” In E. Hobsbawm and T. Ranger (eds), The Invention of Tradition. Cambridge: Cambridge University Press: pp. 1-14.

Hobsbawm, E. On History. London: Weidenfeld and Nicholson. 1997.

Immerwahr, Daniel. “The Fact/Narrative Distinction and Student Examinations in History.” The History Teacher 41(2)(2008): 199-205.

Ingrao, C. (2009). “Weapons of Mass Instruction: Schoolbooks and Democratization in Multiethnic Central Europe.” Journal of Educational Media, Memory, and Society 1(1): 180-189.

Issitt, John. (2004). “Reflections on the study of textbooks.” History of Education 33(6)(2004): 683-696.

Jacobmeyer, W. (1990). International Textbook Research. Goteborg.

Janmaat, Jan. "Ethnic and Civic Conceptions of the Nation in Ukraine’s History Textbooks.” European Education 37.3 (2005): 20-37.

Janmaat, Jan. “The ethnic 'other' in Ukranian history textbooks: the case of Russia and the Russians.” A Journal of Comparative and International Education 35.3 (2007): 307-324.

Kalmus, Veronika. School Textbooks in the Field of Socialization. PhD Diss., University of Tartu: Tartu Estonia, 2003.

Kansteiner, Wolf. (2002). "Finding Meaning in Memory: A methodological critique of collective memory studies.” History and Theory 41(2)(2002): 179-197.

Karlsson, K-G. and Zander U. (eds). (2004). Historien ar nu. En introduktion till historiedaktiken. Lund: Studentlitteratur. 
Krupnikova, Marina. Diversity in Latvian Textbooks. Riga, Latvia: Latvian Centre for Human Rights and Ethnic Studies, 2004.

Kuus, Merje. "European Integration in Identity Narratives in Estonia: A Quest for Security.” Journal of Peace Research 39(1)(2002): 91-108.

Levin, J. and Mayer, R. (1993). "Understanding Illustrations in Text. In B. Britton, A Woodward, and M. Binkley (eds), Learning from Textbooks: Theory and Practice. Hillsdale, NJ: Erlbaum.

Liu, J. H. and Laszlo, J. (2007). "A narrative theory of history and identity: Social identity, social representations, society and the individual.” In G. Moloney and I. Walker (Eds), Social Represenations and History. Palgrave-Macmillan.

Low-Beer, Ann. (2003). “School History, National History and the Issue of National Identity.” International Journal of Historical Learning, Teaching and Research 3(1): 1-6.

Luke, C., de Castell, S., and Luke, A. (1983). "Beyond Criticism: The Authority of the School Text." Curriculum Inquiry 13(2): 111-127.

McCutcheon, G. (1981). "Elementary School Teachers' Planning for Social Studies and Other Subjects." Theory and Research in Social Education 9(1): 45-66.

Mirkovic, Marijana and Crawford, Keith. "Teaching History in Serbian and English Secondary Schools: A cross-cultural analysis of textbooks.” International Journal of Historical Learning, Teaching and Research 3(2)(2003): 91-106.

Neumann, I. B. The Uses of the Other: "The East" in European Identity Formation. Minneapolis, MN: University of Minnesota Press. 1999.

Nichol, J. and Dean, J. (2003) "Writing for Children: History Textbooks and Teaching Texts.” International Journal of Historical Learning, Teaching and Research 3(2): 53-82.

Nicholls, Jason. “Methods in Textbook Research.” International Journal of Historical Learning, Teaching and Research 3(2)(2003): 11-27.

Nicholls, Jason. (2005). “The philosophical underpinnings of school textbook research.” Paradigm 3(1): 24-35.

Nora, Pierre. (1989). “Between Memory and History: Les Lieux de Memoire.” Special Issue: Memory and Counter-Memory 26: 7-24.

Noreen, Erik and Sjostedt, Roxanna. (2004). “Estonian Identity Formations and Threat Framing in the Post-Cold War Era.” Journal of Peace Research 41(6): 733-750. 
Olick, J. and Robbins, J. (1998). "Social Memory Studies: From 'Collective Memory' to the Historical Sociology of Mnemonic Practices." Annual Review of Sociology 24: 105-140.

Olick, Jeffrey. Collective Memory and Chronic Differentiation: Historicity and the Public Sphere. Humanities Research Group Working Papers, 2007. http://www.phaenex.uwindsor.ca/ojs/leddy/index.php/HRG/article/viewFile/371/291.

Olson, David. "On the language and authority of textbooks.” In S. de Castell, A. Luke, and C. Luke (Eds.) Language, Authority and Criticism: Readings on the School Textbook: 233260. New York: The Falmer Press, 1989.

Paabo, Heiko. (2008). "War of Memories: Explaining 'Memorials War' in Estonia.” Baltic Security \& Defense Review 10: 5-28.

Paabo, Heiko. (2010). "From an Eastern Outpost in the West to a Western Outpost in East: The Transformation of the Estonian Master Narrative.” (Unpublished.)

Pingel, F. (1999). UNESCO Guidebook on Textbook Research and Textbook Revision. Hannover: Hahn.

Podeh, E. The Arab-Israeli Conflict in Israeli History Textbooks, 1948-2000. New York: Bergin and Garvey, 2000.

Rannut, M. (2004). Language Policy in Estonia. Revista de Sociolinguistica, Spring-Summer. http://www6.gencat.net/llengcat/noves/hm04primavera-estiu/docs/rannut.pdf.

Richardson, L. (1990). "Narrative and Sociology." Journal of Contemporary Ethnography 19(1): 116-135

Rosser, Yvette. Curriculum as Destiny: Forging national identity in India, Pakistan, and Bangladesh. PhD diss., University of Texas at Austin, 2003.

Schissler, Hanna and Soysal, Yasemin. The Nation, Europe, and the World: Textbooks and Curricula in Transition. Oxford: Berghahn Books, 2005.

Segesten, A. (2008). "History Textbooks in the Balkans: Representations and Conflicts.” In J. Lindbladh (ed) The Poetics of Memory in Post-Totalitarian Narration. The Centre for European Studies at Lund University.

Segesten, A. Myth, Identity and Conflict: A Comparative Analysis of Romanian and Serbian Textbooks. PhD Diss., University of Maryland: College Park, Maryland, 2009. 
"SPIEGEL Interview with Estonian President Toomas Hendrik Ilves.” Spiegel Online International. 26 June 2007. http://www.spiegel.de/international/europe/0,1518,490811,00.html.

Taagepera, R. (1993). Estonia: Return to Independence. Boulder, Colorado: Westview Press.

Theiler, T. (1999). "The European Union and the 'European Dimension' in Schools: Theory and Evidence." European Integration 21: 307-341.

Torsti, Pilvi. (2008). "Security Issue: History Teaching in Post-Conflict Societies.” Canadian Issues Themes Canadiens: 56-59.

Tulviste, P., \& Wertsch, J. V. (1994). “Official and unofficial histories: The case of Estonia.” Journal of Narrative and Life History , 4 (4), 311-329.

Wendt, A. (1994). “Collective Identity Formation and the International State.” American Political Science Review 88(2): 384-396.

Wenzeler, B. (2003). "The Presentation of the Holocaust in German and English School History Textbooks-A Comparative Study.” International Journal of Historical Learning, Teaching and Research 3(2): 107-118.

Woodward, A. (1988). "Introduction." In A. Woodward, D. Elliott, and K. Nagel (eds), Textbooks in school and society: an annotated bibliography and guide to research: 1-22.

Zelizer, B. (1995). "Reading the Past against the Grain: The shape of memory studies.” Critical Studies in Mass Communication 12(2): 214-239. 